\title{
Lithium- and boron-bearing brines in the Central Andes: exploring hydrofacies on the eastern Puna plateau between $23^{\circ}$ and $23^{\circ} 30^{\prime} \mathrm{S}$
}

\author{
R. L. López Steinmetz ${ }^{1}$
}

Received: 23 June 2015 / Accepted: 31 March 2016 / Published online: 14 April 2016

(C) Springer-Verlag Berlin Heidelberg 2016

\begin{abstract}
Internally drained basins of the Andean Plateau are lithium- and boron-bearing systems. The exploration of ionic facies and parental links in a playa lake located in the eastern Puna $\left(23^{\circ}-23^{\circ} 30^{\prime} \mathrm{S}\right)$ was assessed by hydrochemical determinations of residual brines, feed waters and solutions from weathered rocks. Residual brines have been characterized by the $\mathrm{Cl}^{-}$ $\left(\mathrm{SO}_{4}{ }^{2}\right) / \mathrm{Na}^{+}\left(\mathrm{K}^{+}\right)$ratio. Residual brines from the playa lake contain up to $450 \mathrm{mg} / \mathrm{l}$ of boron and up to $125 \mathrm{mg} / \mathrm{l}$ of lithium, and the Las Burras River supplies the most concentrated boron $(20 \mathrm{mg} / \mathrm{l})$ and lithium (3.75 mg/l) inflows of the basin. The hydrogeochemical assessment allowed for the identification of three simultaneous sources of boron: (1) inflow originating from granitic areas of the Aguilar and Tusaquillas ranges; (2) weathering of the Ordovician basement; and (3) boron-rich water from the Las Burras River. Most of the lithium input of the basin is likely generated by present geothermal sources rather than by weathering and leaching of ignimbrites and plutonic rocks. However, XRD analyses of playa lake sediments revealed the presence of lithian micas of clastic origin, including taeniolite and eucriptite. This
\end{abstract}

Editorial handling: T. Bissig

Electronic supplementary material The online version of this article (doi:10.1007/s00126-016-0656-x) contains supplementary material, which is available to authorized users.

R. L. López Steinmetz lucrecialopezsteinmetz@hotmail.com

1 Instituto de Geología y Minería, Universidad Nacional de Jujuy, Av. Bolivia 1661, 4600 S.S. de Jujuy, Argentina study is the first to document these rare Li-micas from the Puna basin. Thus, both residual brines and lithian micas contribute to the total $\mathrm{Li}$ content in the studied hydrologic system.

Keywords Endorheism · Evaporation · Salinity · Hydrochemistry

\section{Introduction}

Internally drained basins of the Andean Plateau are lithium- and boron-bearing systems. The plateau extends from $15^{\circ} \mathrm{S}$ to $27^{\circ} \mathrm{S}$ in the Central Andes and includes both the Bolivian Altiplano to the north, as well as the Puna region (Turner 1972), which extends throughout the north-westernmost areas of Argentina. Within the Puna, Alonso et al. (1984) have differentiated the Northern and Southern Puna, which extend to the north and south of latitude $24^{\circ} \mathrm{S}$, respectively (Fig. 1).

The Puna plateau is a high-altitude region with an arid climate. The regional aridity is controlled by the Cordillera, which constitutes a physical barrier for the humid atmospheric circulation coming from the Atlantic Ocean (Garreaud 2009). Within the Puna, hydrological processes are tightly governed by the high degree of evaporation, which results from the extremely dry climate and high elevation.

Hydrological systems in the Northern Puna are characterized by internally draining basins located at over $3,000 \mathrm{~m}$ a. $\mathrm{s}$. 1. The lower parts of these basins consist of salars and ephemeral salt lakes. These endorheic basins are subject to a negative water balance, as the annual water loss through evaporation exceeds input by far. 


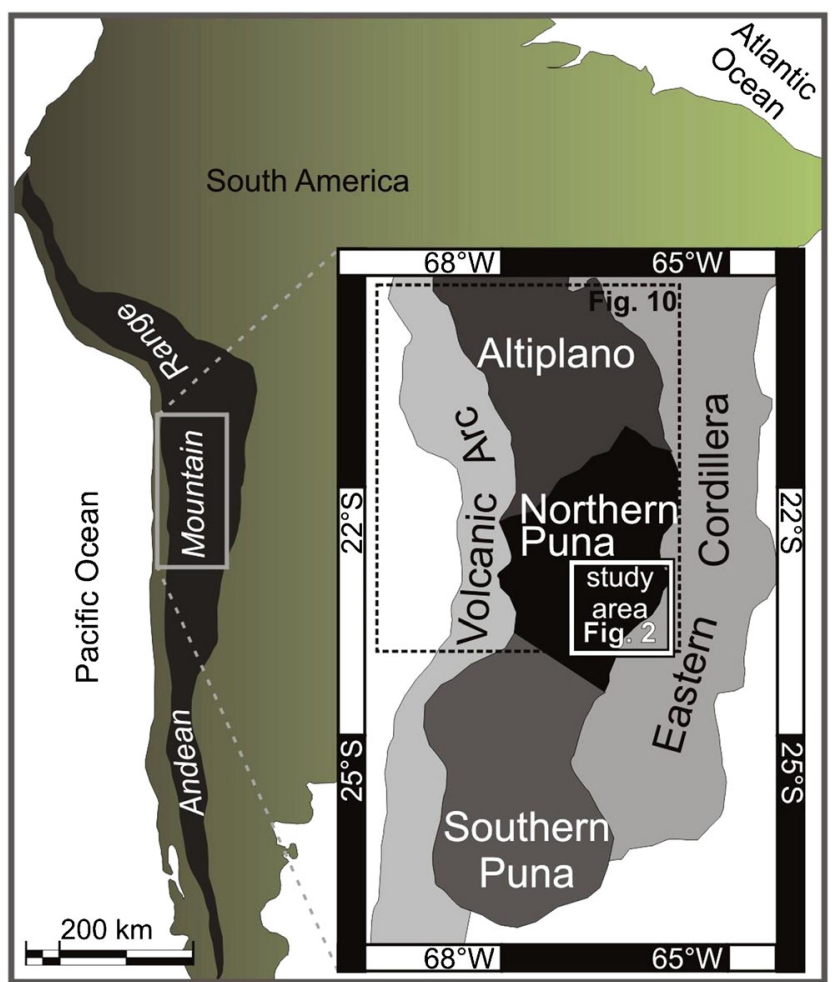

Fig. 1 Location map of the Altiplano-Puna plateau in the Central Andes. The study area is located at $3,400 \mathrm{~m}$ a. s. 1 . in the eastern border of the Northern Puna

Feed waters that have escaped evaporation remain stored within the sedimentary basin fill. These longstanding waters have undergone hydrochemical shifts and became highly ionenriched residual brines. Within the Puna basins, the watertable level of the residual brines varies seasonally: its shift controls the development of salt lakes, playa lakes, and salt pans (Yechieli and Wood 2002). Residual brine-flooded areas (i.e., salt lakes) that are subjected to evaporation lead to the formation of salt pans (or salars). Moreover, the evaporation of residual waters stored within sub-surface sediments (e.g., playa lake environments) causes intra-sedimentary crystallization of salts such as halite and ulexite. Summer rainfalls generate seasonal dilution of the hydrological system. These dilute waters recycle previous evaporites. These regenerated brines are, in turn, subjected to evaporation during a new dry season.

The salinity of these extreme hydrological systems is derived from an array of input sources (Langbein 1961; Eugster and Hardie 1978). For instance, hydrothermal fluids provide major ionic enrichments in this active orogenic region. This hydrothermalism is a remnant of Andean volcanism, with the highest activity occurred during the Upper Miocene and Pliocene (Kay and Coira 2009; Maro 2015). This ionic input is traditionally considered the source of the anomalous boron and lithium concentrations within salars located on the Puna plateau (Rettig et al. 1980; Viramonte et al. 1984; Alonso
1986; Ide and Kunasz 1989; Zhu et al. 1990; Alonso et al. 1991; Zheng and Liu 2009; Lowenstein and Risacher 2009; Munk et al. 2011).

Although meteoric water contains small amounts of most of the main solutes (Eugster 1980), these are negligible compared to other sources in the northern Puna. Unlike meteoric water, leaching and dissolution of pre-existing salts in sedimentary deposits, as well as rock weathering, are important sources of solutes (Hofstra et al. 2013). Some weathering reactions of rocks produce ionic contributions with a predictable composition. For instance, the boron isotopic model proposed by Schmitt et al. (2002) and Kaseman et al. (2004) linked borates formed within salars in the Eastern Puna to weathering processes of basement lithologies. However, most of the ionic litho-parental links remain unidentified in the Puna hydrologic systems.

Regional mining activities focus on extracting evaporites, halite and borates, as well as potassium- and lithium-bearing brines but the salar processes and the hydrochemistry remain poorly documented (Houston et al. 2011). This contribution provides an ionic facies characterization of the lithium- and boron-rich hydrologic system located on the eastern border of the Northern Puna. The study includes hydrochemical analyses of residual brines and a leachate solution of the weathered basement, as well as X-ray diffraction analyses of playa lake sediments. Results contribute to the chemical and mineralogical knowledge of B and Li resources stored within the Puna's salars, which should lead in the future to the optimization of extraction processes.

\section{The study area}

This study focuses on a $\sim 400-\mathrm{km}^{2}$ playa lake system, located at $3,400 \mathrm{~m}$ a. s. 1 . at the eastern border of North Puna $\left(23^{\circ}-\right.$ $22^{\circ} 30^{\prime} \mathrm{S}$ and $65^{\circ} 30^{\prime}-66^{\circ} 45^{\prime} \mathrm{W}$, Fig. 2). The orographic depression that hosts the Guayatayoc playa lake (GPL) is defined by north-south oriented ranges: the Tusaquillas and Cobres Ranges limit the basin on the western side, and the Aguilar, Alta and Chañi Ranges define the eastern margin of the basin.

The GPL concentrates drainage of an endorheic basin with a surface of $\sim 17,000 \mathrm{~km}^{2}$ (López Steinmetz 2013). The fluvial system includes ephemeral and permanent streams. Ephemeral streams are only active during the rainy season during the austral summer (December-March). Most of tributary streams emerge as cold springs with low volume that flow downward across slopes of ranges, infiltrating when they reach the foothill area. Fluvial collectors such as the Miraflores and Las Burras Rivers carry water throughout the year (Fig. 2).

Low annual rainfalls, averaging between 300 and $400 \mathrm{~mm}$, result in a negative water balance, which persists for 10 months of the year, and a relative humidity that barely reaches $47 \%$. 
Fig. 2 Geological map of the study area showing the location of samples. Residual brines $\mathrm{Q}_{0}, \mathrm{G} 3$, and G4 were collected within pits dug in the playa lake. Feed waters were sampled at the headwaters and cold springs, before the stream infiltration Sample Ov is a laboratory leachate from weathered rocks of the Ordovician basement

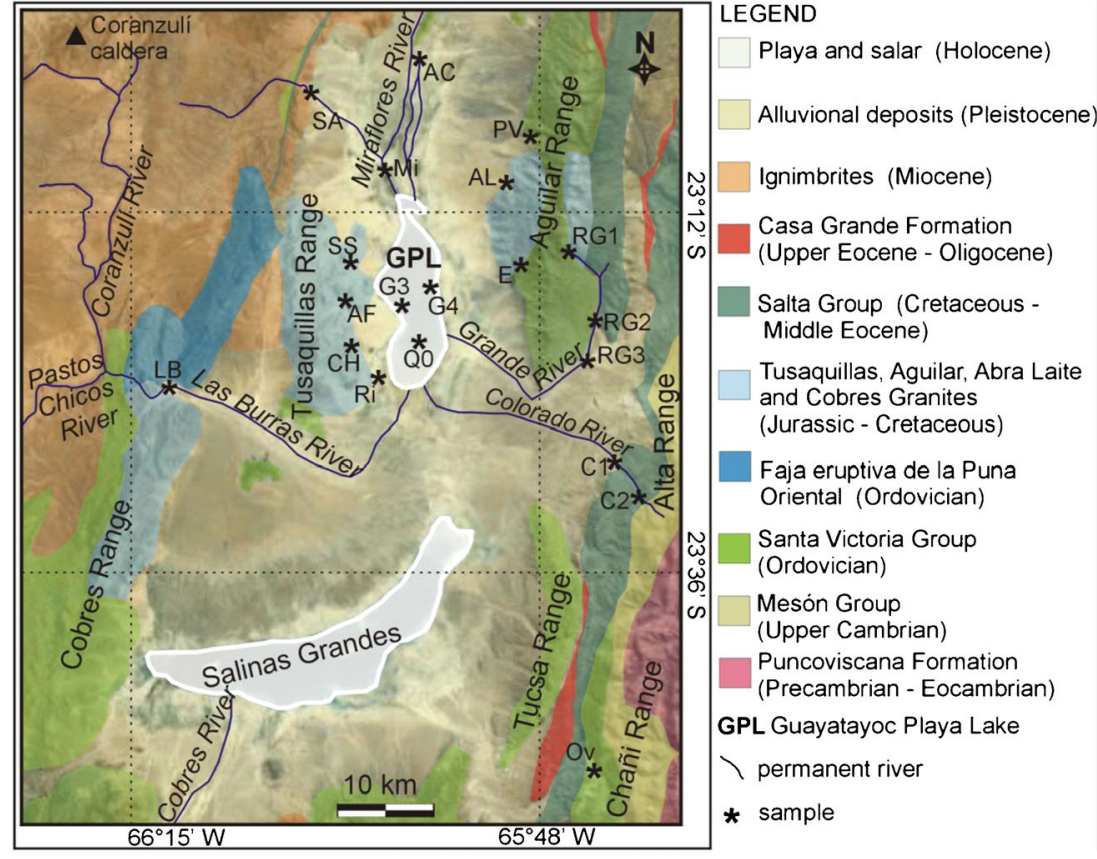

The annual average temperature is $8{ }^{\circ} \mathrm{C}$ and the day-night temperature amplitude is $18^{\circ} \mathrm{C}$ (Bianchi 1981; Buitrago and Larran 1994).

\section{Geological setting}

The GPL is located within the Subprovincia Boratifera of the Eastern Puna which was characterized by the existence of Miocene evaporites and Quaternary salars (Alonso and Viramonte 1985; Alonso 1986). The studied area is surrounded by ranges that expose the basement, including: (1) metasedimentary rocks of the Puncoviscana Formation (Precambrian-Eocambrian; Turner 1960a, b), the Meson Group (Upper Cambrian; Turner Turner 1960a, b), and the Santa Victoria Group (Lower to Middle Ordovician; Turner 1960a); (2) peraluminous plutonic complex of the Faja Eruptiva de la Puna Oriental (Middle to Upper Ordovician; Méndez et al. 1973; Coira et al. 1999; Kirschbaum et al. 2006) that consist of leucogranite, monzogranite and granodiorite (Elortegui Palacios 2011); and (3) Jurassic-Cretaceous granite of Cobres (Toselli and Rossi de Toselli 1977; Zappettini 1989; Menegatti et al. 1997), Aguilar (Coira and Darren 2002), and Tusaquillas (Zappettini 1990; Cristiani et al. 1999), which are composed of diorite, monzonite, two-mica granite (biotitemuscovite), and monzogranite and alkali-feldspathic granite, with dykes of microgranite, muscovitic granite, tourmaline and epidote pegmatite, aplite, alkali-feldspathic and calcalkaline syenite (Zappettini 1990). These plutonic complexes also contain dikes of sovite and alvikite, magnesiocarbonatite, rauhaugite, and beforsite (Santomero 1956; Santomero 1958; Zappettini 1990; Zappettini 1998; Zappettini 2008).
The Cretaceous to Lower-Middle Eocene sedimentary rocks of the rifted Salta Group (Turner 1959) are exposed on the south-eastern border of the GPL, while on the western border, the landscape is covered by a voluminous Upper Miocene ignimbrite platform (Seggiaro and Aniel 1989). The Paleogene and Neogene sedimentary basin fill is largely unknown because of the absence of representative outcrops. Quaternary alluviums extend between the foot of the mountains and the flat areas, which are covered by salt pans and fine-grained sediments. The playa lake environment of Guayatayoc formed during the Holocene, after the retraction of lacustrine stages that were related to the Last Glacial maximum (López Steinmetz and Galli 2015).

\section{Hydrochemical setting}

Hydrochemical studies of basins located in the Andean plateau began during the 1970s (Moraga et al. 1974; Ericksen et al. 1977; Ericksen and Salas 1987; Rettig et al. 1980; Risacher and Fritz 1991; Garcés et al. 1996; López et al. 1996; Alonso and Risacher 1996; Risacher et al. 1998; López Julián and Garcés Millás 2001; Risacher et al. 2002; Banks et al. 2004; Boschetti et al. 2007). A review of the hydrochemical knowledge of Chilean and Bolivian closed basins by Risacher et al. (2003) and Risacher and Fritz (2009), allowed for the recognition of dilute inflow waters produced by weathering of volcanic rocks, and brackish waters originating from recycling of existing brines.

Saline systems of the Puna plateau contain potassium- and lithium-rich brines and evaporites that include halite and a variety of borates dominated by ulexite and borax. Major features of these evaporative facies were investigated by Alonso 
and Viramonte (1985), Yingkai and Lan (2001), Alonso (2006), Vinante and Alonso (2006), and Ovejero Toledo et al. (2009). Furthermore, Schmitt et al. (2002) and Kaseman et al. (2004) identified boron inputs associated with the Paleozoic basement in salars from the Eastern Puna, and boron contributions derived from Neogene ignimbrites in the western part of the plateau.

In the study area, the hydrochemistry of the Miraflores River was described by Alcalde and Alcalde (1978, 1984, 1986) and Bargiela et al. (2007). The presence of ulexite in a cotton-ball-type habit within sediments of the GPL was documented by Reverberi (1968) and Sandruss (1978).

\section{Methods}

For the hydrogeochemical study of the GPL system, residual brines and feed waters were sampled during the dry season (Fig. 2). Three samples of residual brines were collected from 1.7-m-deep pits dug in the playa lake and 16 feed waters were sampled at the headwaters and at cold springs, before the stream infiltration (for location see Fig. 2, the detailed location of samples is stated in the Electronic supplementary material I).

Weathered rocks of the Santa Victoria Group were collected to assess the chemical contribution of the Ordovician basement (sample Ov, Fig. 2). The weathered rock unit is covered by a salt crust (Figs. 3a, b). The rock sample and the salt crust were oven dried at $70{ }^{\circ} \mathrm{C}$ for $10 \mathrm{~h}$. Then $1.8 \mathrm{~kg}$ of the sample was immersed in $1.5 \mathrm{~L}$ of distilled water for $72 \mathrm{~h}$. The aqueous solution was filtered for chemical analysis (sample Ov in Table 1). This procedure was carried out to determine the ionic contribution of the basement weathering to the water chemistry.

Hydrochemical determinations (Table 1) were performed at the Agua de los Andes S. A. laboratory. The electrometric method was used to measure $\mathrm{pH}$ and a Hanna HI2314 multirange conductivity meter was employed to determine conductivity (Clesceri et al. 1998). The total dissolved solids (TDS) were calculated based on conductivity using a conversion $Y=0.202+0.9425 X$, where $X$ represents the conductivity of the sample and $Y$ is the TDS value; with correlation coefficient $R^{2}$ of 0.99 . The concentration of $\mathrm{Ca}^{2+}, \mathrm{Mg}^{2+}, \mathrm{HCO}_{3}{ }^{-}-\mathrm{CO}_{3}{ }^{2}$, and $\mathrm{Cl}^{-}$were determined by EDTA titration, whereas turbidimetry was employed for $\mathrm{SO}^{-}{ }_{4}$ analysis. Colorimetry using carmine was used to determine boron concentrations. $\mathrm{Na}^{+}, \mathrm{K}^{+}$, and $\mathrm{Li}^{+}$determinations were carried out by atomic emission spectroscopy. The error of analytical results was assessed based on the difference between concentrations of cations and anions $\left(R^{2}=0.98\right)$. The ionic evaporative concentration increases with the residence time of waters in the system. In order to compare feed water to residual brines, analytical results were normalized to TDS value.

Additionally, playa lake sediments were collected from 1.7-m-deep pits, depths limited by the brine-water table.
Samples were prepared for X-ray diffraction (XRD) analysis by removing organic matter and carbonate using a $10 \%$ hydrogen peroxide solution. Particle size separation was performed by sieving and decanting the suspension. Sedimentation of clay suspensions were settled on flat sample-holders and air dried. Mineralogical composition of clay fractions were identified by XRD employing a Rigaku Miniflex X-ray diffractometer, with a Cu-anticathode $(1 \mathrm{~kW})$, at the Institute of Geology and Mining of the National University of Jujuy.

Ionic concentrations are represented in brackets, for instance $\left[\mathrm{Cl}^{-}\right]$means the concentration of chloride in a solution in milligrams per liter $(\mathrm{mg} / \mathrm{l})$ and milliequivalents per liter (meq/l). The hydrochemical characterization of a sample is represented using an $\mathrm{A}(\mathrm{B}) / \mathrm{C}(\mathrm{D})$ nomenclature, where the most abundant ion is followed by the second most abundant ion in parenthesis. For example, $\mathrm{Cl}^{-}\left(\mathrm{SO}_{4}{ }^{=}\right) / \mathrm{Na}^{+}\left(\mathrm{K}^{+}\right)$represents a solution in which the concentration of $\mathrm{Cl}^{-}$is greater than that of $\mathrm{SO}_{4}{ }^{=}$.

\section{Results}

\section{Hydrofacies in the Guayatayoc closed system}

The Guayatayoc playa lake is a saline system (Table 1). Streams supply fresh and brackish waters while hyper-saline intra-sedimentary brines characterize the playa lake groundwater (Fig. 3c). Major-permanent flow-rates correspond to the Miraflores and Las Burras Rivers, which are brackish rivers.

Most of samples are $\mathrm{Cl}^{-} / \mathrm{Na}^{+}$type and characterized by $\left[\mathrm{Cl}^{-}\right] \gg\left[\mathrm{Na}^{+}\right]$, while some brackish and fresh waters are $\left[\mathrm{Na}^{+}\right] \geq\left[\mathrm{Cl}^{-}\right]$(Fig. 3d). Samples CH (Río Chico) and R1 (Río Grande 1) have 1:1 ratios of $\left[\mathrm{Cl}^{-}\right] /\left[\mathrm{Na}^{+}\right]$which is evidence for halite dissolution. The GPL is a $\mathrm{Cl}^{-}\left(\mathrm{SO}_{4}{ }^{\circ}\right) / \mathrm{Na}^{+}$ $\left(\mathrm{K}^{+}\right.$) dominated system (Fig. 4a, b, c). Subordinate $\mathrm{HCO}_{3}{ }^{-}-\mathrm{CO}_{3}{ }^{=}, \mathrm{SO}_{4}{ }^{=}$, and $\left[\mathrm{Ca}^{2+}\right] \geq\left[\mathrm{Na}^{+}\right]$hydrofacies characterize inflow waters (Table 1 ). Typically $\mathrm{Cl}^{-}$hypersaline residual brines from the playa lake $\left(\mathrm{G}_{3}, \mathrm{Q}_{0}\right.$, and $\mathrm{G}_{4}$ samples) differentiate from inflow waters based on $\mathrm{K}^{+}$enrichment (Fig. 4c). $\mathrm{SO}_{4}{ }^{=} / \mathrm{Mg}^{2+}$-rich inputs are a distinctive feature of the weathered Ordovician basement as shown by the leachate from sample Ov (Table 1).

Chloride is the dominant anion in hypersaline brines and some brackish waters including samples LB, Ri, AF Mi, and $\mathrm{AC}$ (Fig. 4d, e). Inflows originated in the south easternmost zone are sulphate-rich, brackish waters (samples $\mathrm{C}_{1}, \mathrm{C}_{2}$, and $\mathrm{R}_{3}$ ), whereas meteoric water is characterized by $\mathrm{SO}_{4}{ }^{=}$and $\mathrm{CO}_{3}{ }{ } / \mathrm{HCO}_{3}{ }^{-}$compositions. Therefore, the salinity correlates with anionic facies (Fig. 4d, e).

Carbonate contents decrease from stream waters to residual brines (Fig. 5a). Calcium concentrations are greater than alkalinity $\left(\mathrm{CO}_{3}{ }^{-}+\mathrm{HCO}_{3}{ }^{-}\right)$in all samples, with the exception of the leachate from the weathered basement $(\mathrm{Ov})$, which is 
Fig. 3 a The catchment lithology of the southeastern area is predominantly made up by intensely weathered rocks of the Santa Victoria Group. b These weathered rocks, including the salt crust shown on the picture, were collected to assess the chemical contribution of the Ordovician basement (sample Ov). c Classification of samples according to the salinity. $\mathbf{d}$ Sodium versus chloride. In order to compare feed water to residual brines, analytical results, expressed in milliequivalents per liter, were normalized employing the TDS value. Employed units are in milligram per liter in $\mathrm{C}$ and in milliequivalents per liter in $\mathrm{D}$
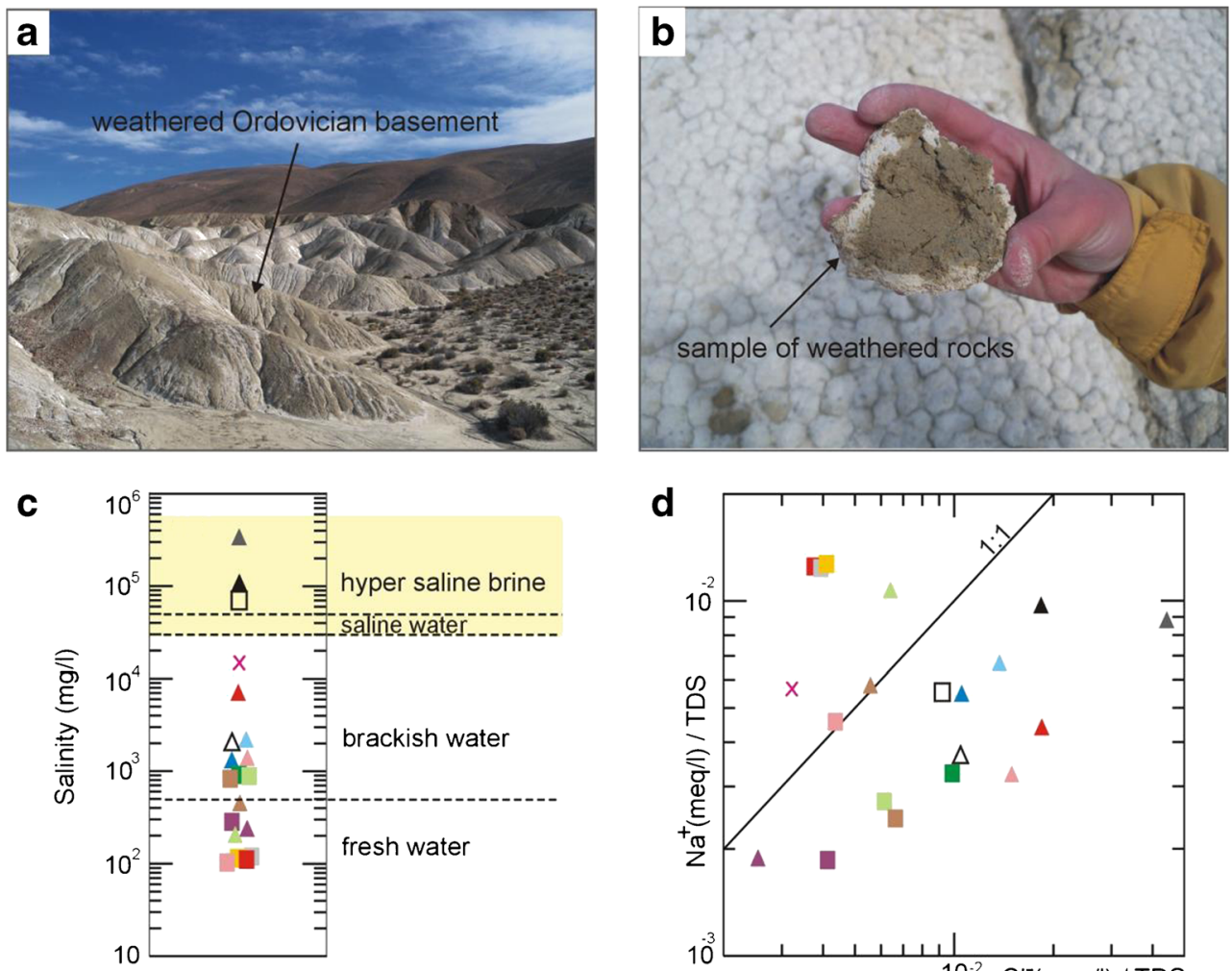

d

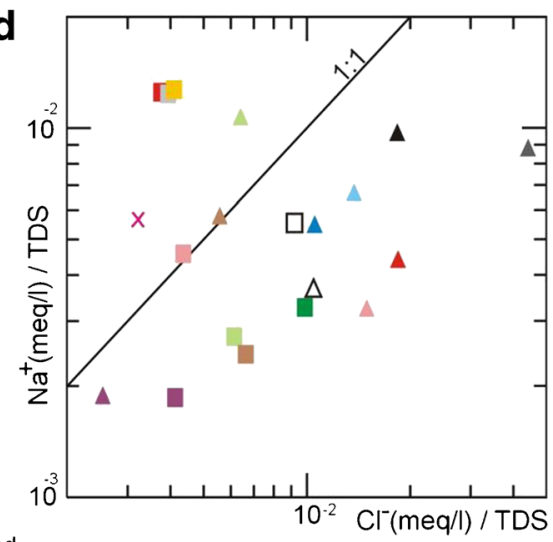

Legend

$\triangle \mathrm{LB} \square \mathrm{PV} \square \mathrm{R} 1 \square \mathrm{C} 1$

$\Delta \mathrm{G} 3 \quad \Delta \mathrm{Mi} \Delta \mathrm{SS}$

$\triangle Q O \triangle A C \quad \triangle C H$

$\Delta \mathrm{RI}$

$\mathrm{AL} \quad \mathrm{R} 2 \quad \square \mathrm{C} 2$

$\square G 4 \quad \triangle S A \quad \triangle A F$ characterized by $\left[\mathrm{Mg}^{2+}\right]>\left[\mathrm{Ca}^{2+}\right]$. Samples from the Miraflores River (Mi) and Rinconadillas (RI) are characterized by $\left[\mathrm{CO}_{3}{ }^{-}+\mathrm{HCO}_{3}{ }^{-}\right] /\left[\mathrm{Ca}^{2+}+\mathrm{Mg}^{2+}\right]$ of 0.8 and 0.82 , respectively (Table 1).

Stream waters are also characterized by $\left[\mathrm{Ca}^{2+}+\mathrm{Mg}^{2+}\right]$-rich facies over $\left[\mathrm{SO}_{4}{ }^{-}\right]$, whereas $\left[\mathrm{SO}_{4}{ }^{-}\right]$concentration increases in residual brines (Fig. 5 b). $\left[\mathrm{SO}_{4}{ }^{-}\right] /\left[\mathrm{Mg}^{2+}\right]$ ratios are $1: 1$ in the leachate from the weathered basement (sample OV), which may also be observed in some samples such as those from the Santa Ana River (SA), from the lower part of the Río Grande River (R3), the Colorados River (C1), and the Rinconadillas cold spring (RI; Table 1). The sulphate-magnesium-dominated input of the basement seems to influence the relationship between $\left[\mathrm{SO}_{4}{ }^{-}+\mathrm{Mg}^{2+}\right]$ and $\left[\mathrm{CO}_{3}{ }^{-}+\mathrm{HCO}_{3}{ }^{-}+\right.$ $\left.\mathrm{Ca}^{2+}\right]$ in streams waters (Fig. $5 \mathrm{c}$ ). Concentrations of $\mathrm{Cl}^{-}+$ $\mathrm{Na}^{+}$are greater than those of $\mathrm{SO}_{4}{ }^{-}+\mathrm{Mg}^{2+}$ in most of samples, except for the SA (Santa Ana), C2 (upper Colorados River), and PV (Pueblo Viejo River) samples (Fig. 5d).

\section{The assessment of potassium, lithium and boron in the GPL}

The highest concentrations of $\mathrm{K}^{+}$, boron, and $\mathrm{Li}^{+}$occur in residual brines from the playa lake (Figs. 6a, b, c, respectively). Streams that originate from granitic ranges are characterized by $\left[\mathrm{K}^{+}\right]$between 2 and $3.5 \mathrm{mg} / \mathrm{l}$ (samples AL, E, $\mathrm{PV}, \mathrm{R} 1$, and SS); whereas $\mathrm{K}^{+}$concentrations reach 8 to $10 \mathrm{mg} /$ 1 in streams traversing a landscape mainly underlain by the Ordovician basement and the Salta Group (samples R2, R3, and $\mathrm{CH}$, Fig. 6a). The presence of $\mathrm{K}^{+}$in the leachate sample Ov indicates that the Ordovician basement also supplies this ionic specie. Increasing concentrations of potassium from 50 to $290 \mathrm{mg} / \mathrm{l}$ in some rivers, such as Aguas Calientes (AC), Las Burras (LB), and Miraflores (MI), suggest the prevalence of mixing processes between dilute streams and residual brines, which are characterized by more than $8,000 \mathrm{mg} / 1$ of potassium.

Dilute inflows include boron concentration less than $0.5 \mathrm{mg} / \mathrm{l}$ (Fig. 6b). Samples from rivers traversing the Ordovician basement have boron concentrations ranging from 1.4 to $3 \mathrm{mg} / \mathrm{l}$. Boron concentrations exceed $300 \mathrm{mg} / \mathrm{l}$ in residual brines from the playa lake.

The highest contents of lithium are observed in the playa lake (Fig. 6c). Lithium concentrations increase from $\sim 1 \mathrm{mg} / 1$ in samples from peripheral areas of the playa lake (samples Mi and $\mathrm{AC}$ ) to $\sim 45 \mathrm{mg} / \mathrm{l}$ in residual brines (samples $\mathrm{G}_{3}$ and $\mathrm{G}_{4}$ ). $\left[\mathrm{Li}^{+}\right]$reaches $125 \mathrm{mg} / \mathrm{l}$ towards the southern central area of the GPL (sample $\mathrm{Q}_{0}$ ). The most concentrated lithium supply 
Table 1 Hydrochemical composition of the GPL's samples

\begin{tabular}{|c|c|c|c|c|c|c|c|c|c|c|c|c|c|}
\hline Sample & $\mathrm{pH}$ & Cond & TDS & $\mathrm{Ca}^{2+}$ & $\mathrm{Mg}^{2+}$ & $\mathrm{Na}^{+}$ & $\mathrm{K}^{+}$ & $\mathrm{Li}^{+}$ & $\mathrm{Cl}^{-}$ & $\mathrm{SO}_{4}=$ & $\mathrm{CO}_{3}=$ & $\mathrm{HCO}_{3}{ }^{-}$ & B \\
\hline $\mathrm{G}_{3}$ & 7.8 & 95,700 & $90,197.4$ & $2,084.0$ & 291.6 & $20,000.0$ & $8,070.0$ & 45.2 & $58,500.0$ & $7,560.0$ & 146.0 & 238.0 & 310.0 \\
\hline $\mathrm{Q}_{0}$ & 7.5 & 171,700 & $161,827.4$ & $1,382.0$ & 133.6 & $32,400.0$ & $21,000.0$ & 125.0 & $252,800.0$ & $13,000.0$ & $-^{\mathrm{a}}$ & 286.0 & 450.0 \\
\hline $\mathrm{G}_{4}$ & 7.6 & 162,000 & $122,525.2$ & $1,270.0$ & 122.5 & $31,700.0$ & $20,870.0$ & 117.0 & $245,090.0$ & $13,500.0$ & $-^{\mathrm{a}}$ & 276.0 & 321.2 \\
\hline $\mathrm{M}_{\mathrm{i}}$ & 9.2 & 8,170 & $7,700.4$ & 86.6 & 5.3 & 766.0 & 292.0 & 1.2 & $5,020.0$ & 400.0 & 42.0 & 166.0 & 8.6 \\
\hline $\mathrm{AC}$ & 8.4 & 1,568 & $1,478.0$ & 66.5 & 10.2 & 109.5 & 63.5 & 1.2 & 790.0 & 175.0 & 4.0 & 86.0 & 0.5 \\
\hline SA & 7.5 & 260 & 245.2 & 25.6 & 7.3 & 10.6 & 7.1 & $-{ }^{b}$ & 22.0 & 90.8 & $-^{\mathrm{a}}$ & 58.0 & 25.6 \\
\hline SS & 7.3 & 188 & 177.4 & 20.2 & 4.6 & 42.9 & 3.5 & $-{ }^{\mathrm{b}}$ & 40.2 & 36.1 & $-^{\mathrm{a}}$ & 38.9 & 1.6 \\
\hline $\mathrm{CH}$ & 8.3 & 405 & 381.9 & 49.6 & 9.2 & 49.2 & 10.3 & $-{ }^{\mathrm{b}}$ & 74.5 & 139.7 & 6.1 & 65.6 & 2.9 \\
\hline $\mathrm{AF}$ & 7.3 & 2,590 & $2,441.3$ & 77.3 & 16.3 & 366.0 & 24.4 & 1.0 & $1,188.0$ & 128.0 & $-^{\mathrm{a}}$ & 63.5 & 6.7 \\
\hline RI & 8.9 & 1,882 & $1,774.0$ & 40.1 & 9.7 & 217.7 & 107.8 & 1.4 & 665.0 & 129.0 & 24.0 & 90.0 & 10.3 \\
\hline LB & 8.0 & 2,480 & $2,337.6$ & 48.7 & 36.4 & 191.3 & 89.9 & 3.7 & 860.0 & 215.3 & 10.0 & 194.0 & 20.0 \\
\hline PV & 7.4 & 80 & 75.6 & 15.1 & 2.5 & 21.8 & 2.4 & $-{ }^{\mathrm{b}}$ & 10.8 & 7.2 & $-^{\mathrm{a}}$ & 38.9 & 0.4 \\
\hline $\mathrm{AL}$ & 7.4 & 82 & 77.5 & 15.0 & 2.0 & 21.8 & 2.0 & $-{ }^{\mathrm{b}}$ & 10.8 & 7.2 & $-^{\mathrm{a}}$ & 39.0 & 0.4 \\
\hline $\mathrm{E}$ & 7.4 & 81 & 76.5 & 15.1 & 2.6 & 21.8 & 2.2 & $-^{\mathrm{b}}$ & 10.8 & 7.0 & $-^{\mathrm{a}}$ & 38.8 & 0.4 \\
\hline $\mathrm{R}_{1}$ & 7.6 & 88 & 83.1 & 12.6 & 3.0 & 8.8 & 3.4 & $-^{\mathrm{b}}$ & 12.7 & 26.0 & $-^{\mathrm{a}}$ & 34.8 & 0.4 \\
\hline$R_{2}$ & 6.8 & 391 & 368.7 & 46.5 & 7.3 & 15.8 & 8.2 & $-{ }^{\mathrm{b}}$ & 54.0 & 77.5 & $-^{\mathrm{a}}$ & 88.0 & 0.5 \\
\hline$R_{3}$ & 10.0 & 945 & 890.9 & 95.8 & 17.3 & 66.8 & 8.3 & $-{ }^{\mathrm{b}}$ & 308.7 & 315.0 & 32.8 & 43.0 & 2.1 \\
\hline$C_{1}$ & 7.9 & 957 & 902.2 & 80.2 & 35.0 & 56.3 & 49.5 & $-^{\mathrm{b}}$ & 195.0 & 302.0 & $-^{\mathrm{a}}$ & 118.0 & 1.4 \\
\hline$C_{2}$ & 8.2 & 842 & 793.8 & 134.0 & 30.0 & 44.6 & 12.6 & $-{ }^{\mathrm{b}}$ & 185.2 & 290.3 & 8.2 & 118.9 & 1.6 \\
\hline OV & 6.2 & 8,880 & $8,369.6$ & 144.3 & $1,433.7$ & 1,294 & 36.0 & $-^{\mathrm{b}}$ & $1,136.8$ & $6,363.5$ & $-^{\mathrm{a}}$ & 26.2 & 0.6 \\
\hline
\end{tabular}

Natural samples include feed waters and residual brines. Sample Ov is an artificial solution obtained from the weathered rocks of the Ordovician basement

Cond conductivity in microsiemens per centimeter, TDS total dissolved solids in milligram per liter, other components in milligram per liter

${ }^{\mathrm{a}} \mathrm{CO}_{3}{ }^{=} / \mathrm{HCO}_{3}{ }^{-}$detection limit $=5 \mathrm{mg} / 1$

${ }^{\mathrm{b}}$ Detection limit for lithium $=0.5 \mathrm{mg} / \mathrm{l}$

corresponds to the Las Burras River, which supplies $3.75 \mathrm{mg} / 1$ of $\mathrm{Li}^{+}$.

Potassium is a major ion and its concentration exceeds those of lithium throughout the system, including residual brines (Fig. 6d). Milliequivalent ratios between concentrations of potassium and boron are typically $\left[\mathrm{K}^{+}\right]>[\mathrm{B}]$ in residual brines, whereas $\left[\mathrm{K}^{+}\right]<[\mathrm{B}]$ reflects the composition of dilute and less saline streams (Fig. 6e). Boron concentrations exceed those of lithium, except in the Aguas Calientes (AC sample), where the $[\mathrm{B}]<\left[\mathrm{Li}^{+}\right]$ratio is caused by low boron rather than from anomalous lithium contents (Fig. 6f). Milliequivalent ratios in residual brines range between $6: 1$ and $13: 1$ for $\mathrm{B} /$ $\mathrm{Li}^{+}, \mathrm{K}^{+} / \mathrm{Li}^{+}$is $30: 1$, and $\mathrm{K}^{+} / \mathrm{B}$ is comprised between $2: 1$ and $4: 1$.

Salinity reflects the time that water resides within the hydrologic system, as evaporation causes increasing ionic enrichment from recently infiltrated waters to residual brines. In order to assess chemical supplies, $\mathrm{K}^{+}-, \mathrm{B}-$, and $\mathrm{Li}^{+}$-rich and diluted solutions were identified in comparison to the normalized concentration of residual brines (Figs. 7a, b, c). Results indicate that tributary rivers only include dilute potassium inflows (Fig. 7d). Multiple B-rich sources were identified, though the main boron input is supplied by the Las
Burras River (Fig. 7e), which also contributes to the unique lithium enrichment of the GSG system (Fig. 7f).

\section{Mineralogy of the playa lake sediments}

The Guayatayoc playa lake is covered by a $2-\mathrm{cm}$ fine-grained crust of halite. Underlying the salty crust, clastic silty-clays are composed of granite fragments, clasts of tabular biotite, subangular plagioclase, pumice, glass shards, and a diatomaceous matrix (López Steinmetz and Galli 2015). Clay fraction includes potassium-rich aluminous silicates, mainly illite, which are often associated with aluminous-kaolinitic mixtures and montmorillonitic silicates rich in $\mathrm{Na}$ over $\mathrm{Mg}$, possibly saponite $(\mathrm{Mg}, \mathrm{Al}, \mathrm{Na}$ ) or montmorillonite $(\mathrm{Al}, \mathrm{Mg}, \mathrm{Na})$.

Results of X-ray diffraction (Fig. 8) indicate that the clay fraction from the playa lake sediments contains rare lithian micas, including taeniolite, whose ideal formula is $\mathrm{KLiMg}_{2} \mathrm{Si}_{4} \mathrm{O}_{10}(\mathrm{~F}, \mathrm{OH})_{2}$, and eucryptite, $\mathrm{Li}(\mathrm{AlSiO} 4)$. These clay fractions from the Guayatayoc playa lake are composed of two different mineral associations, illite-taeniolite (samples $\mathrm{G}_{3}$ and $\mathrm{G}_{4}$ a, Fig. 8a, b), and illite-eucryptite-phlogopite (sample $\mathrm{G}_{4}$ b, Fig. 8c). 
Fig. 4 a Ternary diagram for major anions. b Ternary diagram for sodium, calcium, and magnesium. c Ternary diagram for potassium, calcium, and magnesium. d Hydro-salinity map of the study area. e Anionic facies map of the study area
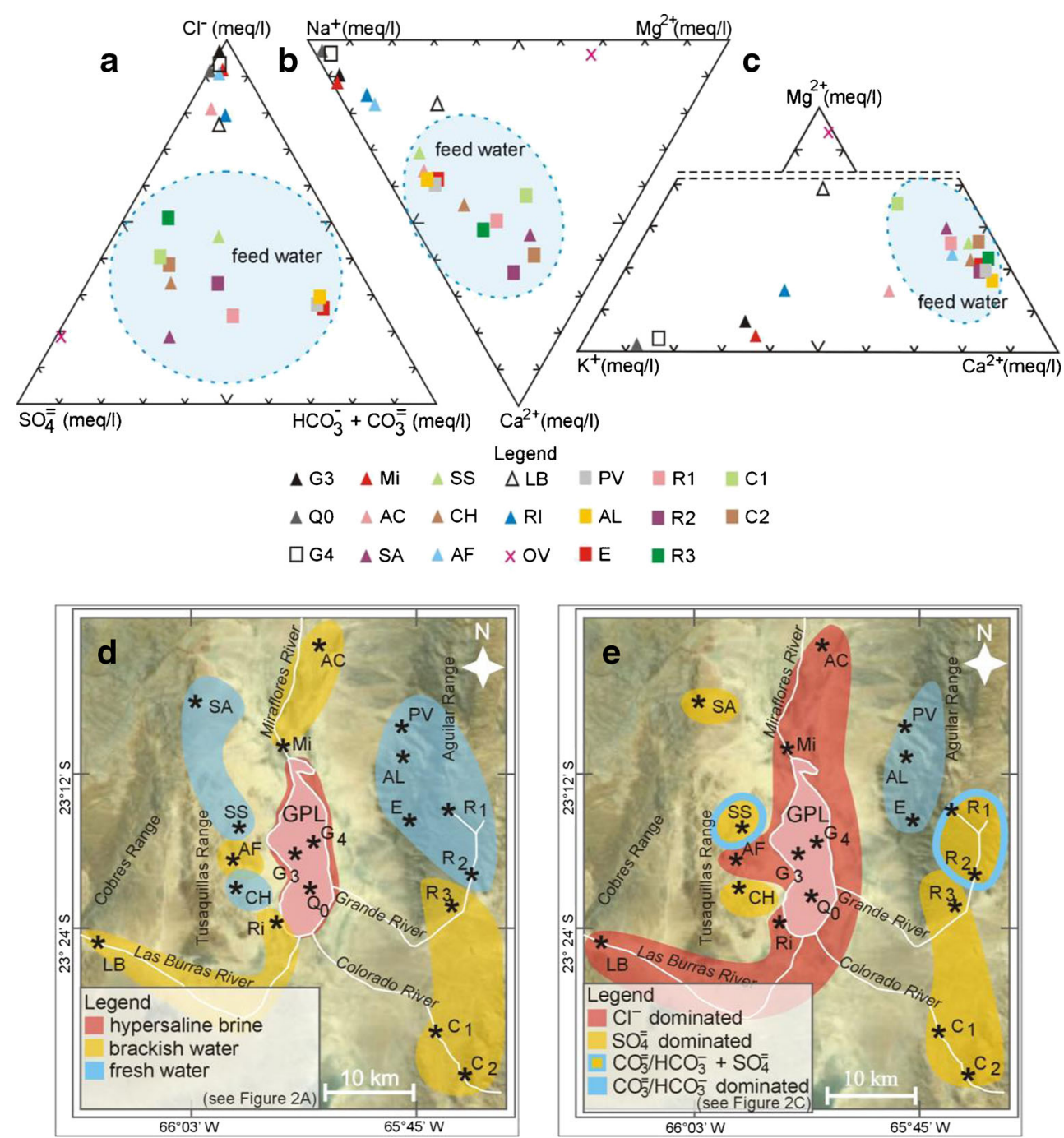

\section{Discussion}

\section{Evolution pathways of evaporating waters}

The chemistry of residual brines is controlled by the initial water composition of inflows (Hardie and Eugster 1970). Evaporation causes the precipitation of insoluble mineral phases and governs the evolutionary pathway of dilute inputs towards residual brines (Eugster 1980; Melvin 1991). The evolutionary pathway (Fig. 10a, b, c) is assessed based on $\mathrm{Ca}^{2+} / \mathrm{HCO}_{3}{ }^{-}-\mathrm{CO}_{3}{ }^{=}$(Hardie and Eugster 1970). Calcite is the first mineral to precipitate from evaporating water. The precipitation of calcite removes $\mathrm{Ca}^{2+}$ and $\mathrm{HCO}_{3}{ }^{-}-\mathrm{CO}_{3}{ }^{=}$from the solution (Fig. 9a). The $\left[\mathrm{Ca}^{2+}\right]$ is greater than alkalinity in dilute inflow water, thus the effect of the evaporative concentration leads to the formation of carbonate-depleted waters. The evolutionary step that follows calcite precipitation depends on the ratio between $\left[\mathrm{HCO}_{3}{ }^{-}+\mathrm{CO}_{3}{ }^{=}\right]$and $\left[\mathrm{SO}_{4}{ }^{=}\right]$ (Hardie and Eugster 1970). $\mathrm{SO}_{4}{ }^{=}$-rich water evolves though the sulphate pathway (direct Fig. 9b, or indirect Fig. 9c) that leads to the dominant $\mathrm{Cl}^{-}\left(\mathrm{SO}_{4}{ }^{-}\right) / \mathrm{Na}^{+}\left(\mathrm{K}^{+}\right)$facies characterizing the GPL's residual brines. The Alfarcito sample (AF) is out of equilibrium and evolves towards calcium-rich water (Fig. 9c). The $\left[\mathrm{HCO}_{3}{ }^{-}+\mathrm{CO}_{3}{ }^{=}\right] /\left[\mathrm{SO}_{4}{ }^{-}\right]$ratio of samples $\mathrm{R} 1$ and $\mathrm{R} 2$ is close to 1:1 (Table 1). Therefore, the ionic input that governs the carbonated PV, AL and $\mathrm{E}$ inflows also influences the evolutionary behavior of samples collected from the upper and middle section of the Grande River (R1 and R2, Table 1).

\section{Solute origins}

The geochemical signature of the sample obtained by leaching the weathered Ordovician rocks $(\mathrm{Ov})$ is $\mathrm{SO}_{4}{ }=\mathrm{Mg}^{2+}$ in miliequivalents is $1: 1$. This ratio indicates recycling evaporites, such as hexahydrite $\left(\mathrm{MgSO}_{4} 6 \mathrm{H}_{2} \mathrm{O}\right)$ or epsomite $\left(\mathrm{MgSO}_{4} 7 \mathrm{H}_{2} \mathrm{O}\right)$, which, in turn, would be formed by weathering of Mg-rich rocks.

The leachate Ov evolves towards the indirect sulphate pathway (Fig. 9c); therefore solutions produced by leaching of the weathered Ordovician meta-sedimentary basement are in equilibrium with the playa lake's residual brines $\mathrm{Cl}^{-}$ 

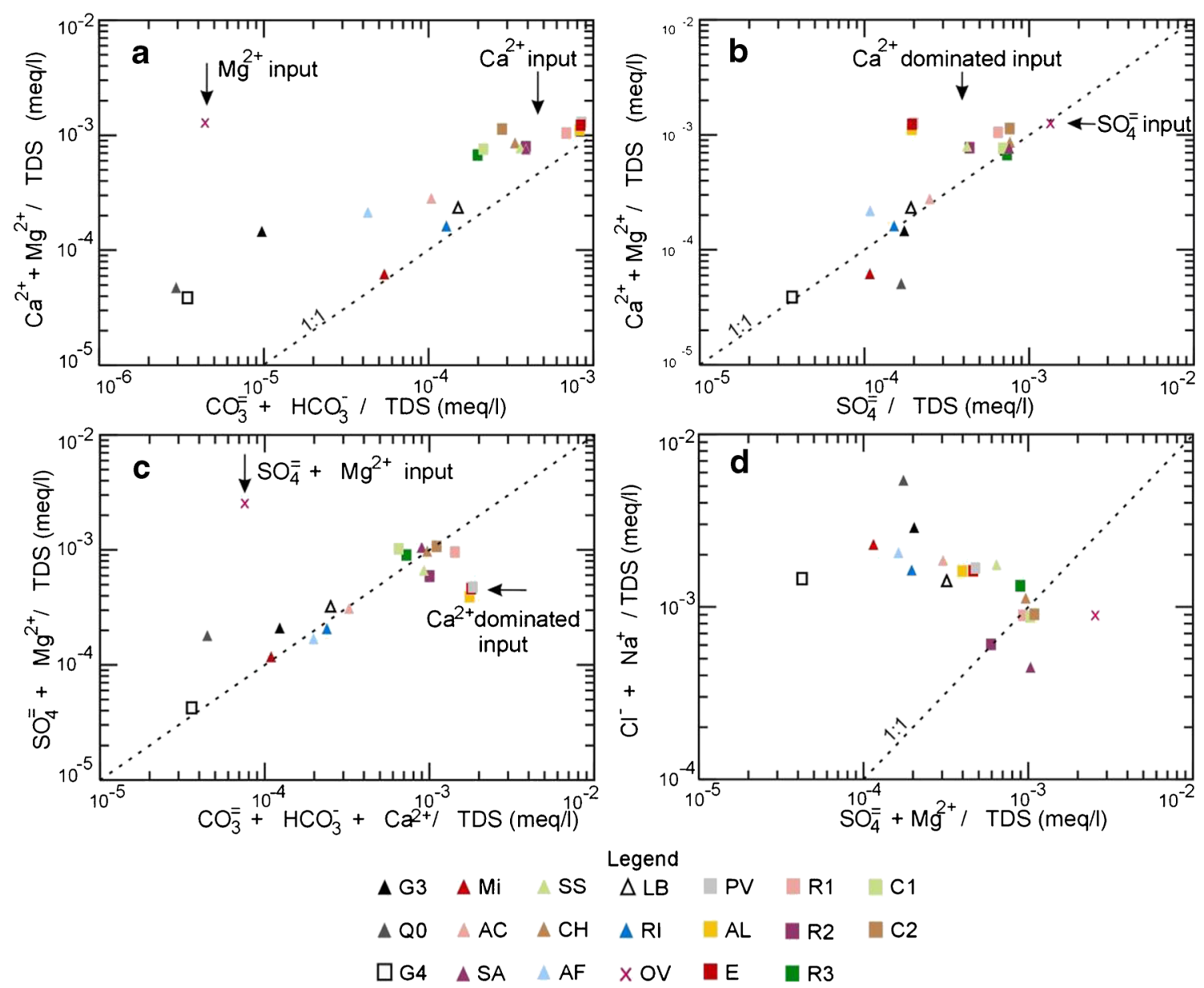

Fig. 5 a Concentration of $\mathrm{Ca}^{2+}$ and $\mathrm{Mg}^{2+}$ versus $\mathrm{CO}_{3}{ }^{-}$and $\mathrm{HCO}_{3}{ }^{-}$. b Concentrations of $\mathrm{Ca}^{2+}$ and $\mathrm{Mg}^{2+}$ versus $\mathrm{SO}_{4}{ }^{2}$. $\mathbf{c}$ Concentration of $\mathrm{SO}_{4}{ }^{=}$ and $\mathrm{Mg}^{2+}$ versus $\mathrm{CO}_{3}{ }^{=}, \mathrm{HCO}_{3}{ }^{-}$, and $\mathrm{Ca}^{2+}$. $\mathbf{d}$ Concentration of $\mathrm{SO}_{4}{ }^{=}$and

$\left(\mathrm{SO}_{4}{ }^{=}\right) / \mathrm{Na}^{+}\left(\mathrm{K}^{+}\right)$. In fact, most of the feed waters in the GPL system evolve towards the sulphate pathway (Fig. 6d). Some calcic-carbonated (Fig. 4a) and sulphate-depleted (Fig. 5) inflows, however, originate from granitic areas of the Aguilar (PV, AL, E samples, Table 1) and Tusaquillas Ranges (AF sample, Table 1). Based on these characteristics, it is possible to distinguish the major ionic inputs and identify their lithoparental links within the GPL system:

1. The $\mathrm{SO}_{4}=/ \mathrm{Mg}^{2+}\left(\mathrm{Na}^{+}\right)$input comes from leaching of the weathered Ordovician meta-sedimentary basement (Santa Victoria Group's rocks). Mg-rich evaporites recycling processes might be involved.

2. The $\mathrm{CO}_{3}{ }^{-}{ }_{-}-\mathrm{HCO}_{3}{ }^{-} / \mathrm{Na}^{+}\left(\mathrm{Ca}^{2+}\right)$ input is related to the Aguilar and Tusaquillas granites. These ionic inputs generate low salinity inflow.

3. The $\mathrm{Na}^{+} / \mathrm{Cl}^{-}$are very soluble species that originate from an array of sources, as evidenced by samples R3 (the lower part of the Río Grande) and SS (Sausalito) in Fig. 4 b. Some of the $\mathrm{Na}^{+} / \mathrm{Cl}^{-}$input would originate by recycling brines and dilution of pre-existing halite, as

$\mathrm{Mg}^{2+}$ versus $\mathrm{Cl}^{-}$and $\mathrm{Na}^{+}$. In order to compare feed water to residual brines, analytical results, expressed in milliequivalents per liter, were normalized employing the TDS value

evidenced by the R1 sample (upper part of the Río Grande) and the $\mathrm{CH}$ sample (Río Chico, Fig. 3d).

These primary ionic inputs produce hydrochemical facies by mixing processes, which are overprinted by evaporative precipitation. Evidence of mixing is represented, for instance, by sample $\mathrm{R} 1, \mathrm{SO}_{4}{ }^{=}\left(\mathrm{CO}_{3}{ }^{-}-\mathrm{HCO}_{3}{ }^{-}\right) / \mathrm{Ca}^{2+}\left(\mathrm{Na}^{+}\right)$, collected in a cold-water spring that emerges through the contact between the Ordovician metasedimentary basement and Mesozoic granites in the southern area of the Aguilar Range. In this sample, the $\mathrm{SO}_{4}{ }^{2}$ and $\mathrm{Na}^{+}$ions would have originated from the metasedimentary basement, whereas $\mathrm{CO}_{3}{ }=-\mathrm{HCO}_{3}{ }^{-}$and $\mathrm{Ca}^{2+}$ would have come from granite.

A potassium-rich facies characterizes residual brines from the playa lake. This feature allows for the recognition of mixtures of meteoric water and residual brines. Thus, mixing is detected in samples Mi, AF, RI and $\mathrm{AC}, \mathrm{Cl}^{-} / \mathrm{Na}^{+}\left(\mathrm{Ca}^{2+}\right)$, based on their relative potassium enrichment (Fig. 6d). Additionally, the areal distribution of chloride-dominated water, especially brackish waters (samples LB, Ri, AF Mi and AC, Fig. 4d and e) can be interpreted as evidence for mixing throughout the low-lying 

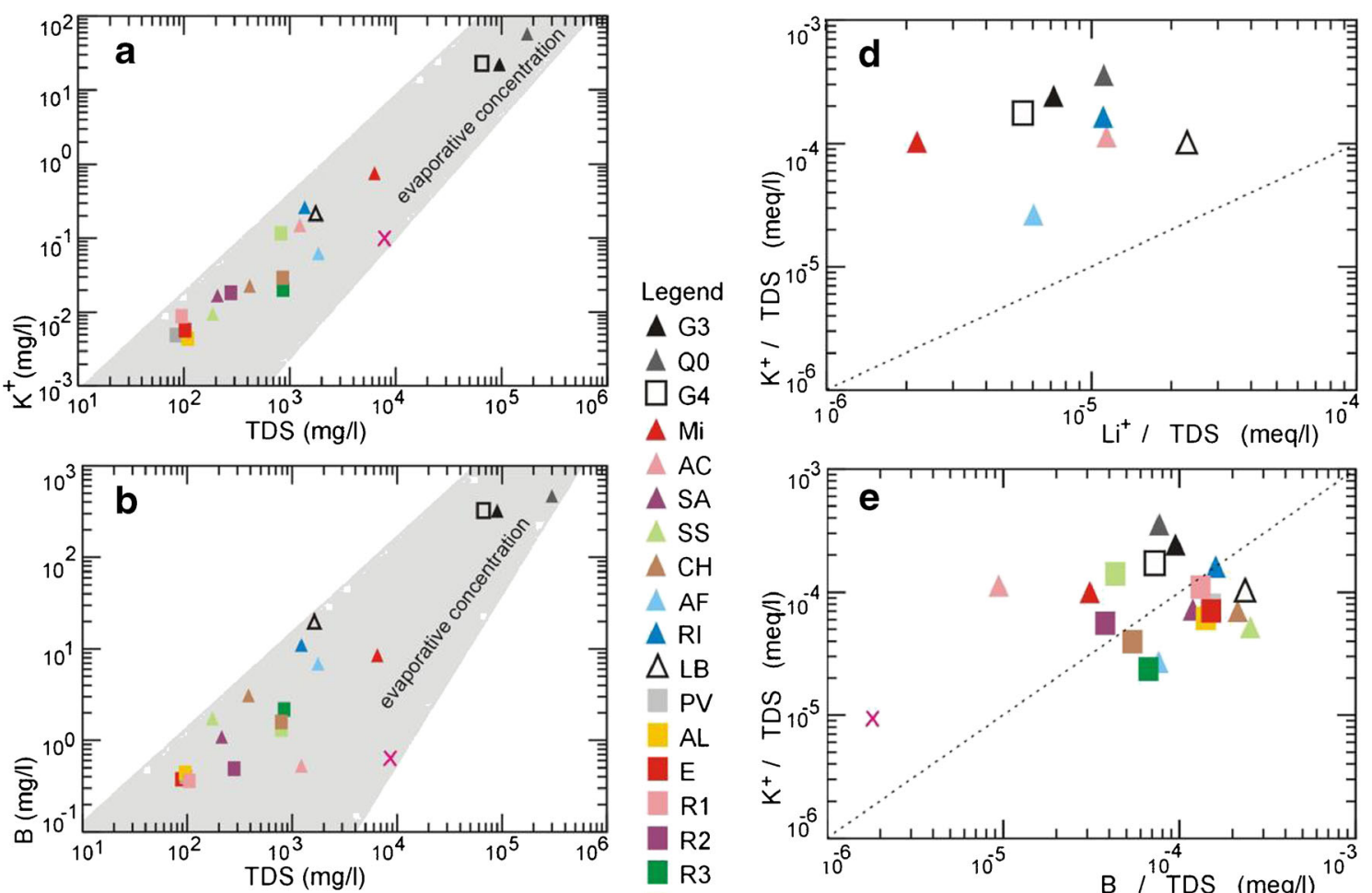

$\triangle A C$
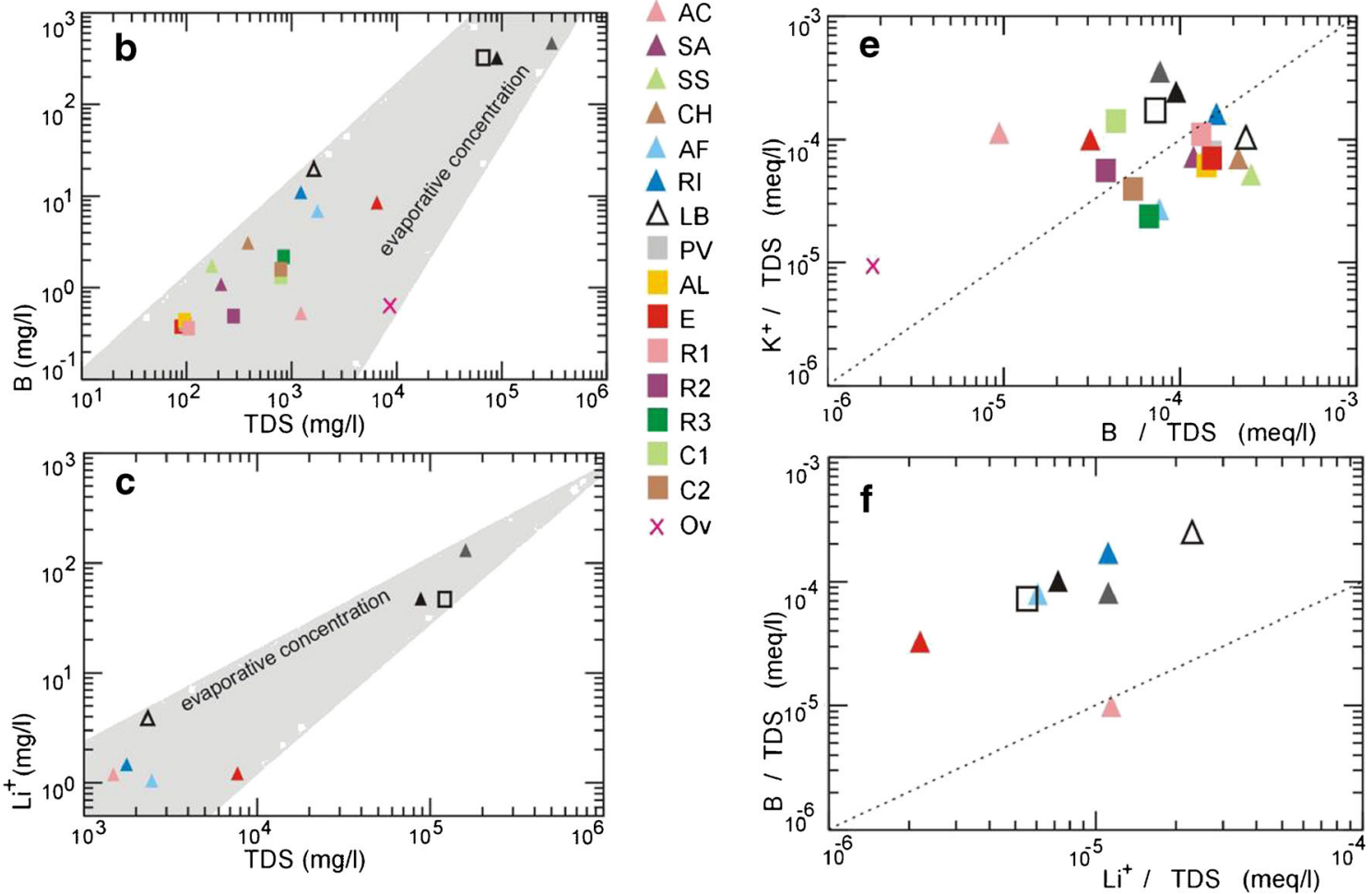

Fig. 6 Concentration of potassium (a), boron (b) and lithium (c) versus TDS, in milligram per liter. Potassium and lithium (d), potassium and boron (e), and boron and lithium (f) are compared using TDS normalized concentrations, expressed in milliequivalents per liter

areas. The composition of brackish rivers, such as the Miraflores and Las Burras, might also be a sign of mixing. Moreover, the boron-rich input of these rivers (Fig. 7b) points to a long-term residence of waters in the systems, which agrees with the large drainage basin of the Las Burras River. Based on these observations, both mixing and long residence times are likely required to form brackish waters.

Residual brines are characterized by heterogeneous ionic concentrations through the GPL. Paleo-shorelines and diatomaceous sediments suggest that the Guayatayoc low-lying areas were submerged during the PleistoceneHolocene transition (López Steinmetz and Galli 2015). The paleolake stage probably resulted from increased fresh water inflows due to melting of glaciers at the end of the Last Glacial Maximum (LGM). The addition of this fresh water would tend to dilute the ionic concentrations of residual brines. The volume of water generated by melting glaciers and the hydrochemical features characterizing the GPL system prior to the LGM remains unknown, however additionally, the present day processes within the plateau's salars involve complex mechanisms that are only superficially understood (Houston et al. 2011). Consequently, the influence of the PlioPleistocene lacustrine phase on the observed areal distribution of ionic concentrations is uncertain and difficult to assess.

The salinity that characterizes the plateau's systems is the result of aridity and endorheism. Additionally, saline hydrologic systems of the Puna region are also related to geothermal, ion-rich volcanic inputs that were active over geologic time-scales. Simultaneously, in the GPL the salinity spatially correlates with hydrologic facies (Fig. 4d, e) and, consequently, salinity might be controlled by parental lithologies. Accordingly to this, ionic inputs from granitic areas 
Fig. 7 Potassium (a), boron (b), and lithium (c), rich and diluted solutions were defined in comparison to residual brines, where normalized concentrations were considered as reference values. Maps group samples within areas characterized by the concentration of potassium (d), boron (e) and lithium (f)
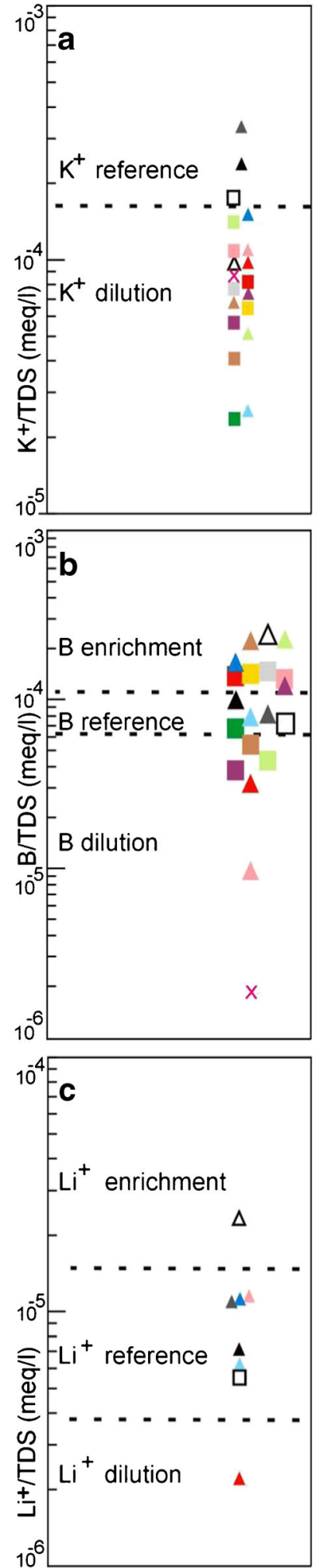
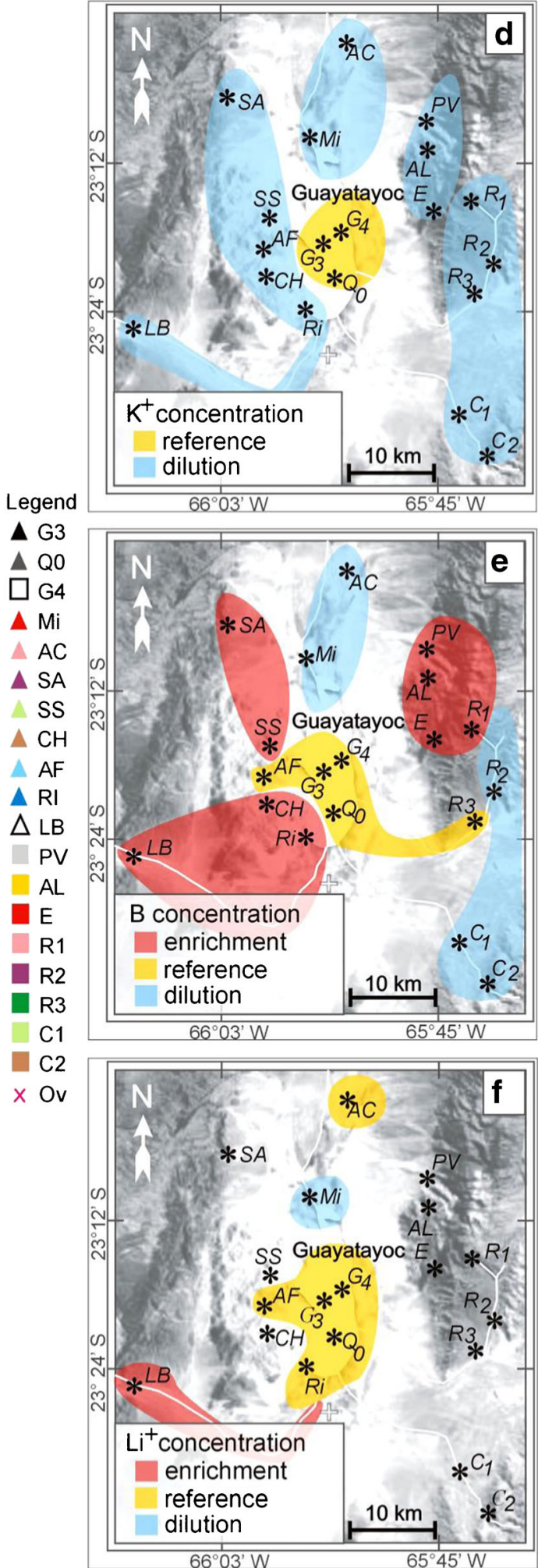

incorporate less salinity than supplies from the Santa Victoria Group (Ordovician Basement) that is widespread in the Northern Puna. These observations agree with the ionic influence of the basement on controlling salinity in the Puna's hydrologic systems.

\section{Boron inputs}

Data allows for the inference of, at least, two different sources of boron within the GPL system. One boron source is suggested by the boron-rich inflow from the Aguilar and 

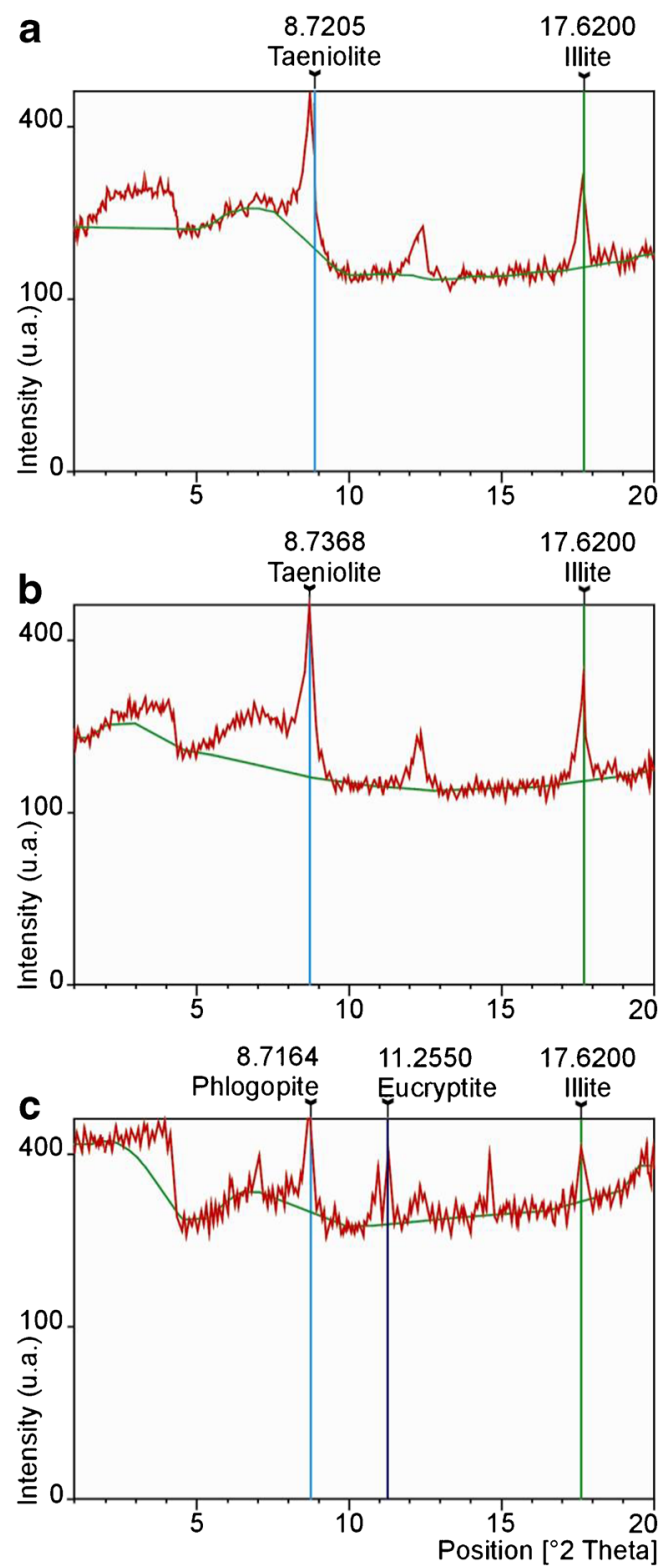

Fig. 8 X-ray diffraction patterns of clay fractions from the playa lake sediments. Diagram A corresponds to sample collected in pit G3, diagrams $\mathrm{B}$ and $\mathrm{C}$ correspond to samples from pit G4. For pit location see Fig. 2

Tusaquillas granitic areas (Fig. 7b). This boron supply might be related to the mineralogical composition of rocks in the catchment area, which include tourmaline-rich granite and pegmatite (Zappettini 1990).

Ulexite $(\mathrm{Ca}-\mathrm{Na}$ borate $)$ in the southeastern portion of the basin (Reverberi 1968; López Steinmetz and Galli 2015) points to an additional $B$ source in the area. The areal drainage is represented by the Grande and Colorados Rivers, which infiltrate before reaching the southeastern border of the playa lake. The catchment of this area is predominantly made up by intensely weathered rocks of the Santa Victoria Group. The hydrochemical assessment of the Ov sample indicates that the

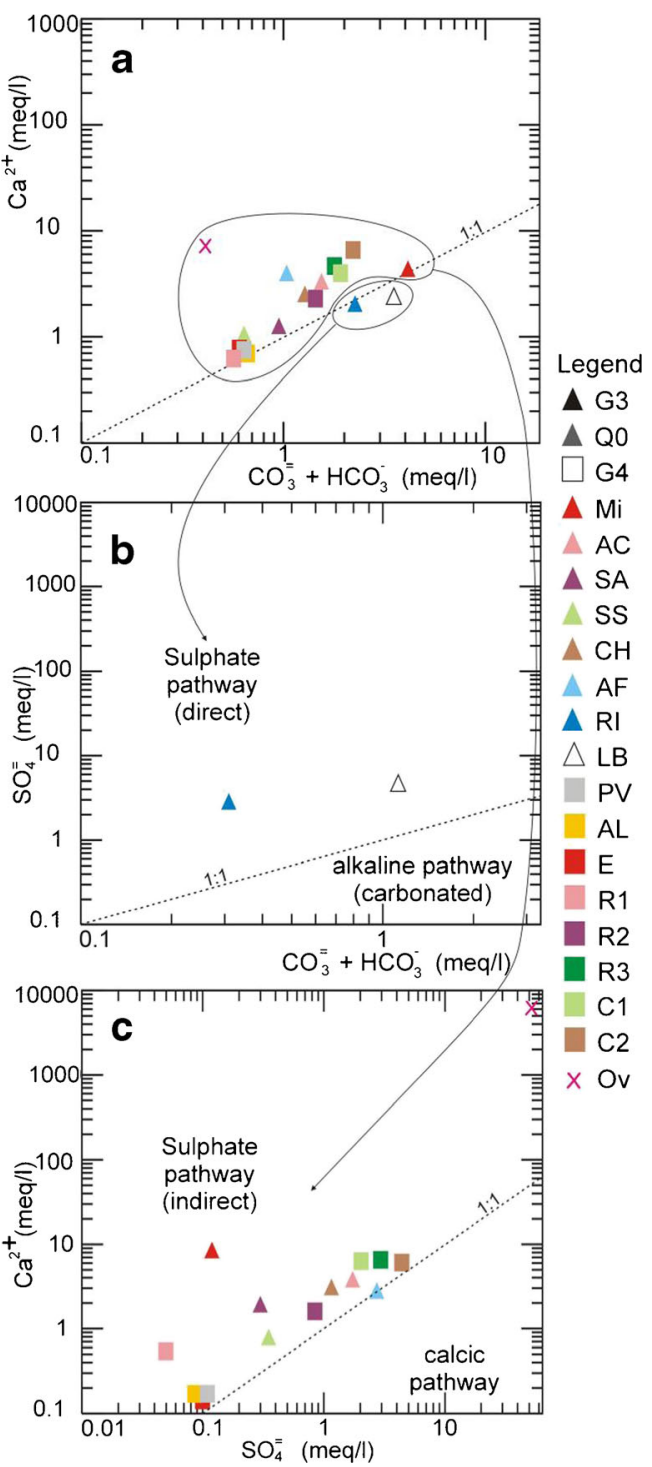

Fig. 9 Steps of the pathway evolution for the GPL's samples: $\mathrm{Ca}^{2+}$ versus $\mathrm{HCO}_{3}{ }^{-}$and $\mathrm{CO}_{3}{ }^{=}(\mathbf{a}), \mathrm{SO}_{4}{ }^{=}$versus $\mathrm{HCO}_{3}{ }^{-}$and $\mathrm{CO}_{3}{ }^{=}(\mathbf{b})$, and $\mathrm{Ca}^{2+}$ versus $\mathrm{SO}_{4}{ }^{=}(\mathbf{c})$

weathered Santa Victoria Group provides some boron supply (Fig. 8b), which would then induce the formation of borates at the southeastern border of the GPL. This source of boron, derived from the weathering of the Paleozoic basement, agrees with isotopic data in borates at Salinas Grandes (Schmitt et al. 2002; Kaseman et al. 2004).

The Las Burras River, similar to the Grande and Colorados Rivers, also infiltrates before reaching the playa lake. Intrasedimentary ulexite has not yet been found within the Las Burras alluvial fan. Despite the fact that this mineral has not been documented, its presence cannot be excluded. Even though the boron source of the Las Burras River is not documented in this study, additional sources of B from geothermal and volcanic activity are possible (Chong et al. 2000). The Las Burras basin includes the Coranzulí River, which originates at 
Table $2 \mathrm{Li}^{+}$concentration of major saline systems and hydrothermal sources in the Central Andes

\begin{tabular}{lllll}
\hline Central Andean Plateau & Basin & Li $^{+}$concentration, mg/l & & References \\
\hline Argentinean Puna & Hombre Muerto Basin & Salar de Hombre Muerto & Up to 1,600 & Godfrey et al. (2013) \\
& Rincón Basin & Salar del Rincón & Up to 449 & Ovejero Toledo et al. (2009) \\
& Caucharí-Olaroz Basin & Salar de Caucharí and Olaroz & Up to 570 & Campellone (2010) \\
& Salinas Grandes Basin & Guayatayoc Playa Lake & Up to 125 & this study \\
& & Las Burras River & 3.7 & this study \\
$\begin{array}{l}\text { Chilean Puna de } \\
\text { Atacama }\end{array}$ & Atacama Basin & Salar de Atacama & Up to 6,400 & Moraga et al. (1974) \\
Bolivian Altiplano & Laguna Colorada Basin & Laguna Colorada & Up to 165 & Scandiffio and Alvarez (1990) \\
& & Spring and fumaroles at Laguna & 53 & Scandiffio and Alvarez (1990) \\
& Poopó Basin & Carcamaya Spring & 5 & Risacher and Fritz (1991) \\
& Calama Basin & Geysers of El Tatio & Up to 47 & Scandiffio and Alvarez (1990) \\
& Coipasa Basin & Salar of Coipasa & Up to 82 & Ericksen et al. (1977); Lebrun et al. (2002) \\
& & Sajama Springs & Up to 7.4 & Scandiffio and Rodríguez (1990) \\
& & Lauca River & 3.6 & Scandiffio and Rodríguez (1990) \\
& Uyuni Basin & Salar of Uyuni & Up to 4,720 & Ericksen et al. (1977); Risacher and \\
& & Fritz (1991); Schmidt (2010)
\end{tabular}

The list is not exhaustive and only includes the major Li-bearing systems shown in Fig. 10

the foot of the Coranzulí Volcano (Fig. 2). The Coranzulí River emerges from geothermal springs, flows across the Loma Blanca Mine (a large volcanic-related, tincal-ulexite deposit, Alonso et al. 1988; Alonso 1999) and continues southwards until its confluence with the Las Burras River. The boron concentration of the Las Burras River would therefore originate from geothermal input and leaching of the Loma Blanca mineralization.

\section{Lithium input}

The lithium in salars is widely proposed to originate from weathering of felsic volcanic rocks and/or geothermal activity (Rettig et al. 1980; Viramonte et al. 1984; Ide and Kunasz 1989; Zhu et al. 1990; Vinante and Alonso 2006; Gibert et al. 2009; Lowenstein and Risacher 2009; Zheng and Liu 2009; Munk et al. 2011; Godfrey et al. 2013). The Li-rich inflow of the Las Burras River provides the principal lithium input $(3.7 \mathrm{mg} / \mathrm{l})$ of the GPL system. The northern catchment area of Las Burras Basin is covered by the Coranzulí ignimbrite (Fig. 2). Erosion of this ignimbrite during $6.62 \mathrm{Ma}$ removed $\sim 18 \mathrm{~km}^{3}$ of rocks (Seggiaro 1994; Seggiaro and Aniel 1989). When considering mean values for $\mathrm{Li}$ concentration in other Neogene ignimbrites from the Puna plateau $(53 \mathrm{mg} / \mathrm{kg}$, Siebel et al. 2001) and rock density $\left(2,610 \mathrm{~kg} / \mathrm{m}^{3}\right.$, González Losa et al. 2004), erosion of ignimbrite would have supplied 2.4 MT of $\mathrm{Li}$ into the salar. This estimation is in agreement with the efficiency of weathering in generating $\mathrm{Li}^{+}$from volcanic rocks pointed by Hofstra et al. (2013). However, the Li content of the Coranzuli ignimbrite remains unknown and the total mass of Li being released from rocks is possibly over estimated because only a part of the total amount of $\mathrm{Li}$ becomes free $\mathrm{Li}^{+}$.

Lithian-micas recorded in the GPL sediments include potassic-lithian micas (taeniolite) and a taeniolite-phlogopite association (Cooper et al. 1995; Tischendorf et al. 1997). Lithian-micas are igneous, thus, their occurrence within the playa lake sediments suggests that in addition to the erosion of volcanic rocks such as ignimbrites, the erosion of plutonic rocks also removes lithium. The Tusaquillas, Cobres and Aguilar Ranges include granitic pegmatites that may contain Li (Zappettini 1990; Garret 2004; Stilling et al. 2006; Munk et al. 2011; Kesler et al. 2012). Additionally, the Tusaquillas complex is intruded by carbonatite dykes that may contain lithian-micas (Cooper et al. 1995).

\section{Geothermal systems}

Regional Li-bearing geothermal systems are reported across the plateau (Table 2, Fig. 10). Geothermal springs are rich in lithium and represent larger systems at depth. The reported $\mathrm{Li}$ concentrations in springs represent minimal values of $\mathrm{Li}$ incorporated from hydrothermal systems into ground waters.

Most rivers that flow into Andean salars are sourced from volcanic catchment areas with active geothermal springs. However, these rivers have lower concentrations of lithium than geothermal springs, due to mixing and dilution with meteoric 


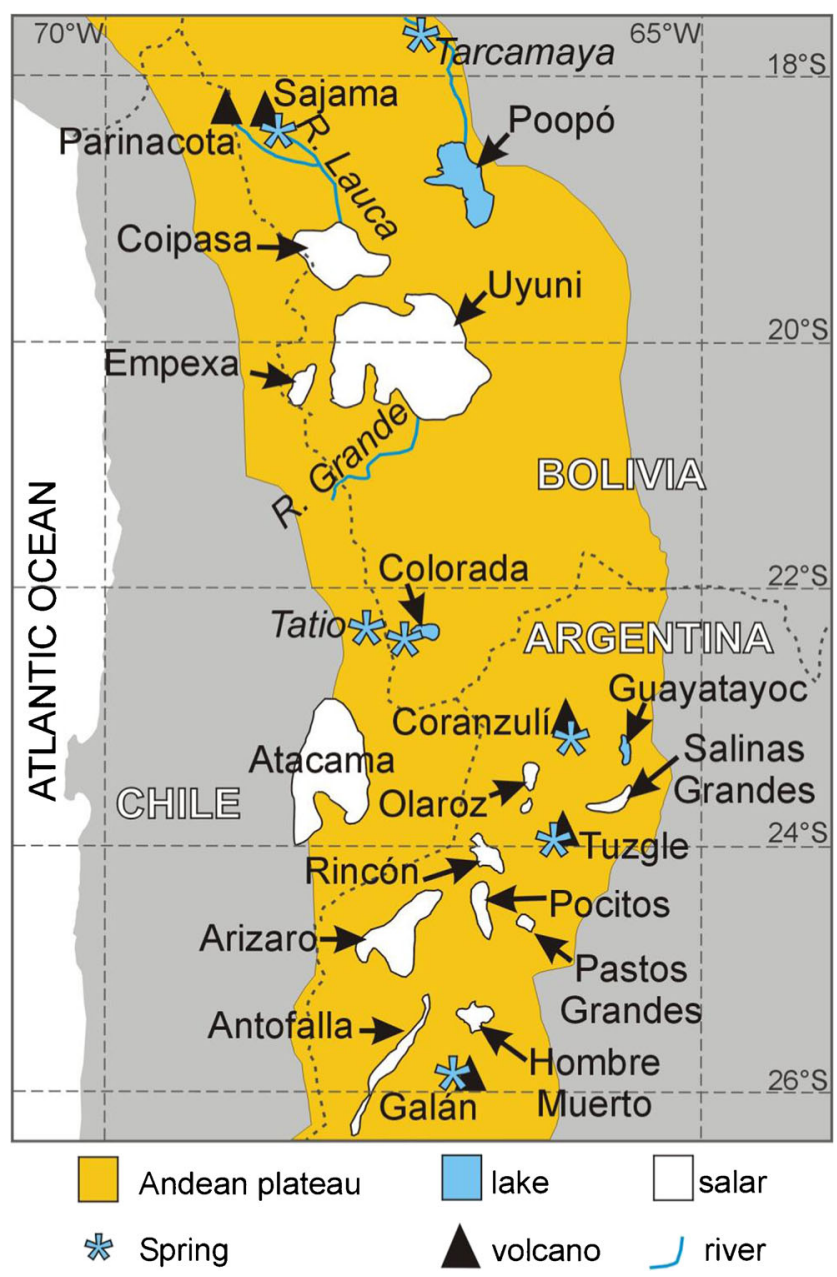

Fig. 10 Location map of major saline systems in the Central Andes. The map only shows springs from geothermal fields referred in Table 2. Uyuni is the biggest salar in the Central Andes and contain up to $4,720 \mathrm{mg} / \mathrm{l}$ of $\mathrm{Li}^{+}$(Risacher and Fritz 1991). The Salar of Atacama contains the highest known concentrations of lithium (Moraga et al. 1974)

water (Table 2). In the GPL Basin, Li-bearing geothermal springs are currently active in the Coranzuli caldera (Alonso et al. 1988; Alonso 1999; Kasemann et al. 2004) and the Tuzgle volcano (Fig. 10; Aquater 1981; Mon 1987; Coira and Mahlburg Kay 1993; Sainato and Pomposiello 1997; Matteini et al. 2002; Giordano et al. 2013). These geothermal springs contain up to $17 \mathrm{mg} / \mathrm{l}$ of lithium (Panarello et al. 1990) and feed the Las Burras River, which supplies $3.7 \mathrm{mg} / 1$ of $\mathrm{Li}^{+}$into the GPL.

In summary, the lithium-bearing brines of the GPL originate by different processes. The GPL receives Li-rich water and Li-bearing sediment loads. Weathering and erosion of volcanic (ignimbrites) and plutonic rocks (granites and carbonatites) produce a part of the Li supply. However, the $\mathrm{Li}$ input from rock-weathering is less significant than that from geothermalism.

The Las Burras River provides the principal Li input of the GPL system and thus denotes an attractive area to explore Li sources. Additionally, López Steinmetz and Galli (2015) showed that the Las Burras River mostly drained into the Salinas Grandes during the progradation of the Las Burras alluvial fan and until the Pleistocene. Accordingly, lithiumbearing brines are expected to be present in the Salinas Grandes.

\section{Conclusion}

A framework is proposed to characterize hydrologic facies and to recognize links in the lithium- and boron-bearing hydrologic system that occupies the eastern border of Northern Puna. This closed basin is characterized by $\mathrm{Cl}^{-}\left(\mathrm{SO}_{4}{ }^{=}\right) / \mathrm{Na}^{+}$ $\left(\mathrm{K}^{+}\right)$brines hosted within sediments of a playa lake. (1) The $\mathrm{SO}_{4}=/ \mathrm{Mg}^{2+}\left(\mathrm{Na}^{+}\right)$input originates by leaching of the weathered Ordovician meta-sedimentary basement; (2) the $\mathrm{CO}_{3}{ }^{=}-\mathrm{HCO}_{3}{ }^{-} \mathrm{Na}^{+}\left(\mathrm{Ca}^{2+}\right)$ and low salinity inflow is related to the Aguilar and Tusaquillas granites; and (3) the $\mathrm{Na}^{+} / \mathrm{Cl}^{-}$ input is from an array of sources, including recycled brines and dilution of pre-existing halite. The Santa Victoria Group likely sourced much of the total salinity that characterizes the Northern Puna hydrologic systems.

Residual brines from the playa lake contain up to $450 \mathrm{mg} / \mathrm{l}$ of boron from three simultaneous sources: (1) boron-rich inflow from the granitic areas of Aguilar and Tusaquillas; (2) input from the highly weathered rocks of the Santa Victoria Group; and (3) the Las Burras River.

In addition to boron, residual brines also contain up to $125 \mathrm{mg} / 1$ of lithium. The Las Burras River provides the most concentrated lithium input $(3.75 \mathrm{mg} / \mathrm{l})$ to the GPL system. Therefore, the Las Burras basin denotes an attractive area for lithium exploration.

Lithian-micas within sediments have been eroded from plutonic rocks of the Tusaquillas complex. Additional Li inputs might involve weathering and leaching of ignimbrites. However, the major lithium supply originates from geothermal systems.

Acknowledgments This study was supported by the PRH Red 101 ANPCyT of the Argentina National Government, and the National University of Jujuy. The laboratory of Aguas de los Andes S. A. provided lab facilities and the Institute of Geology and Mining of Jujuy supplied XRD facilities and field logistics. The author thanks the reviewers Thomas Bissig and Brian Townley and the editor Georges Beaudoin for their constructive comments, which substantially improved the manuscript.

\section{References}

Alcalde JA, Alcalde M (1978) Calidad del agua en la cuenca del rio Miraflores, Departamento Cochinoca, Jujuy. Rev del Inst de Geol, 3, 123-132, Jujuy

Alcalde JA, Alcalde M (1984) Exploración hidrogeológica de la Puna, Provincia de Jujuy. $9^{\circ}$. Congr Geol Argentino, Actas 6, 320-334 
Alcalde JA, Alcalde M (1986) Exploración hidrogeológica de la cuenca del río Miraflores, Provincia de Jujuy, Argentina. Rev del Inst de Geol, 6, 211-255, Jujuy

Alonso RN (1986) Ocurrencia, posición estratigráfica y génesis de los depósitos de boratos de la Puna argentina. Ph.D. thesis, Facultad de Ciencias Naturales, Univ Nac de Salta, 196 p

Alonso RN (1999) Los salares de la Puna y sus recursos evaporíticos (Jujuy, Salta y Catamarca). In: Zappettini E O (ed) Recursos Minerales de la República Argentina, Inst de Geol y Rec Minerales, SEGEMAR, Anales 35, 1779-1826, Buenos Aires

Alonso RN (2006) Ambientes evaporíticos continentales de Argentina. INSUGEO 21:155-170

Alonso H, Risacher F (1996) Geoquímica del Salar de Atacama, parte 1: origen de los componentes y balance salino. Rev Geol de Chile 23(2):113-122

Alonso RN, Viramonte JG (1985) Provincia boratífera centroandina. $4^{\circ}$ Congr Geol Chileno, Actas 2 (3), 45-63

Alonso RN, Gutiérrez R, Viramonte J (1984) Puna Austral - Bases para el subprovincialismo geológico de la Puna Argentina. 9o Congr Geol Argentino, Actas 1, 43-63

Alonso RN, Helvaci C, Sureda RJ, Viramonte JG (1988) A new Tertiary borax deposit in the Andes. Miner Deposita 23(4):299-305

Alonso RN, Jordan TE, Tabbutt KT, Vandervoort DS (1991) Giant evaporite belts of the Neogene Central Andes. Geology 19:401-404

Aquater (1981) Exploración geotérmica en el área del Cerro Tuzgle, provincia de Jujuy, República Argentina. Estudio de prefactibilidad. Sec de Minería de la Prov de Jujuy, 123 p, Jujuy, Argentina

Banks D, Markland H, Smith PV, Mendez C, Rodriguez J, Huerta A, Saether OM (2004) Distribution, salinity and pH dependence of elements in surface waters of the catchment areas of the Salars of Coipasa and Uyuni, Bolivian Altiplano. J of Geochem Explor 84: 141-166

Bargiela M, Navone S, Maggi A, Kindgard A (2007) Estudio de la mineralización del agua en cursos de la cuenca del río Miraflores y la laguna de Guayatayoc (Jujuy). Actas del $21^{\circ}$ Congr Nac del Agua, $1-9$

Bianchi AR (1981) Las precipitaciones en el noroeste argentino. INTA, Estación Exper Regional Agropecuaria Salta, $48 \mathrm{p}$

Boschetti T, Cortecci G, Barbieri M, Mussi M (2007) New and past geochemical data on fresh to brine waters of the Salar de Atacama and Andean Altiplano, northern Chile. Geofluids 7:33-50

Buitrago LG, Larran MT (1994) El clima de la Provincia de Jujuy. Cátedra de Climatología y Fenología Agrícola, Facultad de Ciencias Agrarias, Univ Nac de Jujuy, $44 \mathrm{p}$

Campellone S (2010) Estimacion de Reervas de Litio Proyecto CaucharíOlaroz EXAR Minera, www.lithiumamericas.com, Acces AGO/ 2010, 23 p.

Chong G, Pueyo JJ, Demergasso C (2000) The borate deposits in Chile. Revista Geológica de Chile 27:99-119

Clesceri LS, Greenberg AE, Eaton AD (1998) Standard Methods for the Examination of Water and Waste Water. Amer Public Health Assoc, $20^{\text {th }}$ Edition, USA.

Coira B, Darren J (2002) Magmatismo ultrabásico-básico alcalino sinextensional arenigiano en el flanco sudoccidental de la Sierra de Aguilar, Provincia de Jujuy. $15^{\circ}$ Congr Geol Argentino, Actas 2, 122-127.

Coira B, Mahlburg Kay S (1993) Implications of the Quaternary volcanism at Cerro Tuzgle for crustal and mantle evolution of the Puna Plateau, Central Andes, Argentina. Contr to Mineral and Petr 113(1):40-58

Coira B, Kay S, Pérez B, Woll B, Hanning M, Flores P (1999) Magmatic sources and tectonic setting of Gondwana margin Ordovician magmas, northern Puna of Argentina and Chile. In: Ramos VA, Keppie D (eds) Laurentia Gondwana connections before Pangea, vol 336, Geol Soc of Am, Spe Paper., pp 145-171
Cooper AF, Paterson LA, Reid DL (1995) Lithium in carbonatites - consequence of an enriched mantle source? Mineral Mag 59:401-408

Cristiani C, Del Moro A, Matteini M, Mazzuoli R, Omarini R (1999) The Magmatism linked to the Jurassic-Cretaceous rift of NW Argentina: the Tusaquillas plutonic complex (Central Andes). $14^{\circ}$ Congr Geol Argentino, Actas 2, 190-193.

de Silva SL, Gosnold WD (2007) Episodic construction of batholiths: insights from the spatiotemporal development of an ignimbrite flare-up. J Volcanol Geotherm Res 167:320-335

Elortegui Palacios J (2011) Petrología y genesis del leucogranito Las Burras y rocas plutónicas asociadas (Faja Magmática Oriental), Puna jujeña. Ph.D. thesis, Univ Nac de Córdoba, 332p.

Ericksen GE, Salas R (1987) Geology and resources of salars in the central Andes. U.S. Geol. Surv. Open File Rep. 88-210, 51 p.

Ericksen GE, Vine JD, Ballon R (1977) Lithium-rich brines at Salar de Uyuni and nearby salars in southwestern Bolivia. U.S. Geol. Surv. Open-File Rep., 77-615, 52 p.

Eugster HP (1980) Geochemistry of evaporitic lacustrine deposits. Ann Rev Earth Planet Sciences 8:35-63

Eugster HP, Hardie LA (1978) Saline lakes. In: Lerman A (ed) Chemistry, Geology and physics of Lakes. Springer, 273-293.

Garcés I, López PL, Auqué LF, Chong G, Vallès V, Gimeno MJ (1996) Características geoquímicas generales del sistema salino del Salar de Llamara (Chile). Est Geol 52:23-35

Garreaud RD (2009) The Andes climate and weather. Adv in Geosci 22: $3-11$

Garret DE (2004) Handbook of lithium and natural calcium chloridetheir deposits, processing, uses and properties. Bostom. Elsevier Academic Press, Amsterdam, p 476

Gibert RO, Taberner C, Sáez A, Giralt S, Alonso RA, Edwards RL, Pueyo $\mathrm{JJ}$ (2009) Igneous origin of $\mathrm{CO}_{2}$ in ancient and recent hot-spring waters and travertines from the northern Argentinean Andes. J Sedimentary Res 79:554-567

Giordano G, Pinton A, Cianfarra P, Baez W, Chiodi A, Viramonte J, Norini G, Groppelli G (2013) Structural control on geotermal circulation in the Cerro Tuzgle-Tocomar geotermal volcanic area (Puna plateau, Argentina). J of Volc and Geotherm Res 249:77-94

Godfrey LV, Chan L-H, Alonso RN, Lowenstein TK, McDonough WF, Houston J, Li J, Bobst A, Jordan TE (2013) The role of climate in the accumulation of lithium-rich brine in the Central Andes. Appl Geochem 38:92-102

González Losa A, Pérez Torrado FJ, Lomoschitz Mora Figueroa A (2004) Aproximación al comportamiento geotécnico de las ignimbritas ash and pumice a partir de análisis químico-mineralógicos. Geo-Temas 6(3):293-295

Hardie LA, Eugster HP (1970) The evolution of closed-basin brines. Mineral Soc of Am Spe Pub Paper 3:273-290

Hofstra AH, Todorov TI, Mercer CN, Adams DT, Marsh EE (2013) Silicate melt inclusion evidence for extreme pre-eruptive enrichment and post-eruptive depletion of lithium in silicic volcanic rocks of the Western United States: Implications for the origin of lithium-rich brines. Economic Geology 108:1691-1701

Houston J, Butcher A, Ehren P, Evans K, Godfrey L (2011) The evaluation of brine prospects and the requirement for modifications to filing standards. Economic Geology 106:1225-1239

Ide F, Kunasz IA (1989) Origin of lithium in Salar de Atacama, northern Chile. In: Ericksen GE, Cañas Pinochet MT, Reinemund JA (eds) Geology of the Andes and its relation to hydrocarbon and mineral resources, vol 11, Circum-Pacific Council for Energy and Mineral Resources, Earth Sci Series., pp 165-172

Kaseman SA, Meixner A, Erzinger J, Viramonte JG, Alonso RN, Franz G (2004) Boron isotope composition of the geothermal fluids and borate minerals from salar deposits (Central Andes/NW Argentina). J of South Am Earth Sci 16:685-697

Kay SM, Coira BL (2009) Shallowing and steepening subduction zones, continental lithospheric loss, magmatism, and crustal flow under the 
Central Andean Altiplano-Puna Plateau. In: Kay S, Ramos VA, Dickinson WR (eds) Backbone of the Americas: shallow subduction, plateau uplift, and ridge and terrane collision, vol 204, Geol Soc of Am, Mem., pp 229-259

Kesler SE, Gruber PW, Medina PA, Keoleian GA, Everson MP, Wallington TJ (2012) Global lithium resources: relative importance of pegmatites, brine and other deposits. Ore Geol Rev 48:55-69

Kirschbaum A, Hongn F, Menegatti N (2006) The Cobres Plutonic Complex, eastern Puna (NW Argentina): petrological and structural constrains for Lower Paleozoic magmatism. J of South Am Earth Scie 21:252-266

Langbein WB (1961) Salinity and hydrology of closed lakes. US Geol Survey Professional Paper 412, p. 20.

Lebrun V, Pacosillo P, Gutierrez J, Caceres F, Pool E, Pirard E (2002) Geochemistry of bitter brines in the Salar de Coipasa-Bolivia. Aardkundige Mededelingen 12:21-24

López Julián PL, Garcés Millás IM (2001) Relaciones geoquímicas entre los distintos tipos de aguas superficiales del salar de Surire (Chile), Departamento Ciencias de la Tierra, Univ de Zaragoza, p. 10

López Steinmetz RL (2013) Génesis y evolución de la Laguna de Guayatayoc, Puna jujeña. Ph.D. thesis, Univ. Nac. de Salta, p. 300.

López Steinmetz RL, Galli CI (2015) Hydrological change during the Pleistocene-Holocene transition associated with the Last Glacial Maximum-Altithermal in the eastern border of Northern Puna. Andean Geol 42(1):1-19

López PL, Auqué LF, Garcés I, Chong G, Vallès V, Gimeno MJ (1996) Aplicaciones de la modelización geoquímica al estudio de pautas evolutivas en las salmueras del Salar de Llamara (Chile). Aproximación de método inverso. Estudios Geol 52:197-209

Lowenstein T, Risacher F (2009) Closed basin brine evolution and the influence of $\mathrm{Ca}-\mathrm{Cl}$ inflow waters. Death Valley and Bristol Dry Lake, California, Qaidam Basin, China, and Salar de Atacama. Chile Aquat Geochem 15:71-94

Maro G (2015) Modelo eruptivo y pertogénesis del magmatismo monogenético neógeno de Puna Norte. Ph.D. thesis, Univ Nac de Salta, p. 403.

Matteini M, Mazuoli R, Omarini R, Cas R, Maas R (2002) The geochemical variations of the cenozoic volcanism along the CalamaOlacapato-El Toro transversal fault system in the central Andes $\left(\sim 24^{\circ} \mathrm{S}\right)$ : petrogenetic and geodynamic implications. Tectonophysics 345(1-4):211-227

Melvin JL (1991) Evaporites, Pteroleum and Mineral Resources. Developments in Sedimentology, 50. Ed. Elsevier, p. 556.

Méndez V, Navarini A, Plaza D, Viera O (1973) Faja Eruptiva de la Puna oriental. $5^{\circ}$ Congr Geol Argentino, Actas 4, 89-100.

Menegatti N, Omarini R, Del Moro A, Mazzuoli R (1997) El granito alcalino de la Sierra de Rangel (Cretácico inferior), Provincia de Salta, Argentina. $8^{\circ}$ Congr Geol Chileno, Actas 2, 1379-1384.

Mon R (1987) Structural geology of two geothermal areas in the andes: Copahue and Tuzgle (Argentina). Bull of the Int Assoc of Engin Geol 35(1):79-85

Moraga A, Chong G, Fortt MA, Henríquez H (1974) Estudio geológico del salar de Atacama, Provincia de Antofagasta. Boletín del Instituto de Investigaciones Geológicas 29:1-56

Munk LA, Bradley DC, Hynek SA, Chamberlain CP (2011) Origin and evolution of Li-rich brines at Clayton Valley, Nevada, USA. http:// static.coreapps.net/agu2011/html/V13B-2602.html/- accessed 7 January 2011.

Ovejero Toledo A, Alonso RN, Ruiz TV, Quiroga AG (2009) Evapofacies halíticas del Salar del Rincón, Departamento de los Andes, Salta. Rev Geol Argentina 64(3):493-500

Panarello H, Sierra JL, Pedro G (1990) Flow patterns at the TuzgleTocomar geotermal system, Salta- Jujuy, Argentina. Geothermal investigations with isotopes and geochemical techniques in Latin America, Proceed of a Final Res Co-ordination Meeting, San José, $57-76$.
Rettig SL, Jones BF, Risacher F (1980) Geochemical evolution of brines in the Salar de Uyuni. Bolivia Chem Geol 30:57-79

Reverberi OV (1968) Contribución al estudio de los yacimientos de boratos de Argentina. Laguna Guayatayoc. Departamentos Cochinoca y Tumbaya. Provincia de Jujuy. Informe, Inst Nac de Geol y Min, Subsecretaría de Minería y Combustibles, Jujuy, 68 p.

Risacher F, Fritz B (1991) Quaternary geochemical evolution of the Salar of Uyuni and Coipasa, Central Altiplano, Bolivia. Chem Geol 90: 211-231

Risacher F, Fritz B (2009) Origin of salt and brine evolution of Bolivian and Chilean Salars. Aquat Geochem 15:123-157

Risacher F, Alonso H, Salazar C (1998) Geoquímica de aguas en cuencas cerradas I, II y II Regiones Chile. Informe, DGA-UCN-ORSTOM, p. 140.

Risacher F, Alonso H, Salazar C (2002) Hydrochemistry of two adjacent saline lakes in the Andes of northern Chile. Chem Geol 187:39-57

Risacher F, Alonso H, Salazar C (2003) The origin of brines and salts in Chilean Salars: a hydrochemical review. Earth Sci Rev 63:249-292

Sainato CM, Pomposiello MC (1997) Two-dimensional magnetotelluric and gravity models of the Tuzgle volcano zone (Jujuy province, Argentina). J of South Am Earth Sci 10(3-4):247-261

Sandruss AE (1978) Estudio geológico-minero del yacimiento boratífero de Laguna de Guayatayoc. Distrito Quebraleña. Departamentos: Cochinoca-Tumbaya. Provi de Jujuy. Informe, Dir Prov de Minería, Jujuy, p. 78.

Santomero AM (1956) El yacimiento de torio de Rangel. Comisión Nac de Energía Atómica, Buenos Aires, p. 56.

Santomero AM (1958) Las manifestaciones toríferas de la Serranía de Rangel, Departamento La Poma, Prov de Salta. Com Nac de Energía Atómica, Buenos Aires, p. 58.

Scandiffio G, Alvarez M (1990) Informe geoquímico sobre la zona geotérmica de Laguna Colorada, Bolivia. Geothermal investigations with isotope and geochemical techniques in Latin American, Proc. of a Final Res. Co-ordination Meeting, Organismo Internacional de Energía Atómica, Costa Rica, 77-113.

Scandiffio G, Rodríguez J (1990) Geochemical report on the Sajama geothermal area, Bolivia. Geothermal investigations with isotope and geochemical techniques in Latin American, Proc of a Final Res Co-ordination Meeting, Organismo Internacional de Energía Atómica, Costa Rica, 114-168.

Schmidt N (2010) Hydrogeological and hydrochemical investigations at the Salar de Uyuni (Bolivia) with regard to the extraction of lithium. FOG - Freiberg Online Geoscience 26:1-131

Schmitt AK, Kaseman S, Meixner A, Rhede D (2002) Boron in central Andean ignimbrites: implications for crustal boron cycles in an active continental margin. Chem Geol 183:333-347

Seggiaro RE (1994) Petrología, geoquímica y mecanismos de erupción del complejo volcánico Coranzulí. Ph.D. Thesis, Universidad Nacioanl de Salta, pp. 181

Seggiaro RE, Aniel B (1989) Los ciclos piroclásticos del área TiomayoCoranzulí, Provincia de Jujuy. Rev de la Asoc Geol Argentina 44: 394-401

Siebel W, Schnurr WB, Hahne K, Kraemer B, Trumbull RB, van den Bogaard P, Emmermann R (2001) Geochemistry and isotope systematic on small- to medium-volume Neogene-Quaternary ignimbrites in the southern central Andes: evidence for derivation from andesitic magma sources. Chem Geol 171(3-4):213-237

Stilling A, Cerny P, Vanstone PJ (2006) The Tanco pegmatite at Bernic Lake, Manitoba. XVI. Zonal and bulk compositions and the petrogenetic significance. Can Mineral 44:599-623

Tischendorf G, Förster H-J, Trumbull RB (1997) On Li-bearing micas: estimating $\mathrm{Li}$ from electron microprobe analyses and an improved diagram for graphical representation. Mineralogical Magazine 61: 809-834 
Toselli A, Rossi de Toselli JN (1977) El plutón alcalino de la Sierra de Cobres, Provincia de Salta, Argentina. Acta Geol Lilloana 13(5): $169-185$

Turner JC (1959) Estratigrafía del Cordón de Escaya y la Sierra de Rinconada, Jujuy. Rev de la Asoc Geol Argentina 15(1):15-39

Turner JC (1960a) Estratigrafía de la Sierra de Santa Victoria y adyacencias. Bol de la Acad Nac de Ciencias 41(2):163-169, Córdoba

Turner JC (1960b) Estratigrafía del Nevado de Cachi y sector al oeste (Salta). Acta Geol Lilloana 3:191-226

Turner JC (1972) Puna. Geología Regional Argentina, 1, 13-56. Buenos Aires.

Vinante D, Alonso RN (2006) Evapofacies del Salar del Hombre Muerto, Puna Argentina: distribución y génesis. Rev de la Asoc Geol Argentina 61(2):286-297

Viramonte J, Alonso RN, Gutierrez R, Argañaraz R (1984) Génesis del litio en salares de la Puna argentina. $9^{\circ}$ Congr Geol Argentino, Actas $3,471-481$

Yechieli Y, Wood W (2002) Hydrogeologic processes in saline systems: playas, sabkhas and saline lakes. Earth Sci Rev 58:343-365

Yingkai X, Lan W (2001) The effect of $\mathrm{pH}$ and temperature on the isotopic fractionation of boron between brine and sediments. Chem Geol 171:253-261
Zappettini E (1989) Geología y metalogénesis de la región comprendida entre las localidades de Santa Ana y Cobres, Provincias de Jujuy y Salta. República Argentina. Ph.D. thesis, Univ de Buenos Aires, 189 p.

Zappettini E (1990) Proyecto de prospección de las áreas Quepente y Tusaquillas, Provincia de Jujuy, Informe, Secretaría de Minería y Recursos Energéticos de la Provincia de Jujuy, Dir Gral de Fabricaciones Militares, Jujuy, p. 90.

Zappettini E (1998) Depósitos de tierras raras y torio de la Puna y Cordillera Oriental, Jujuy y Salta. In: Zappettini E (ed) Recursos Minerales de la República Argentina, vol 35, Inst de Geol y Recursos Minerales SEGEMAR, Anales., pp 979-985, Buenos Aires

Zappettini E (2008) Metalogénesis asociada al plutonismo mesozoico en Jujuy, in: Coira, B., Zappettini, E. (Eds.), Geología y Recursos Naturales de la Provincia de Jujuy. 17. Congr Geol Argentino, Rel, 259-262.

Zheng M, Liu X (2009) Hydrochemistry of salt lakes of the QinghaiTibet plateau. China Aquat Geochem 15:293-320

Zhu Y, Zhengyan L, Bihau W, Wang M (1990) The formation of thte Qarhan saline lakes as viewed in the light of neotectonic movement. Acta Geol Sin 3:247-259 